\title{
The Challenges of Curbing North-South Migration of Teenage Girls in Ghana
}

\author{
Georgina Ansong \\ Beautiful Creation Group of Company of Accra, Accra, Ghana \\ Email: ginasong2001@yahoo.com
}

How to cite this paper: Ansong, G. (2022). The Challenges of Curbing North-South Migration of Teenage Girls in Ghana. American Journal of Industrial and Business Management, 12, 231-276.

https://doi.org/10.4236/ajibm.2022.122014

Received: December 3, 2021

Accepted: February 25, 2022

Published: February 28, 2022

Copyright (อ 2022 by author(s) and Scientific Research Publishing Inc. This work is licensed under the Creative Commons Attribution International License (CC BY 4.0).

http://creativecommons.org/licenses/by/4.0/ (c) (i) Open Access

\begin{abstract}
Internal migration of the youth especially teenage girls from the five Northern regions of Ghana to the cities of Accra and Kumasi has persisted for over three decades yet no concrete strategies have been put in place to curb the drift which is damaging the human capital base of the country in general and the North in particular. The study therefore examined the challenges bedeviling efforts by stakeholders at curbing the trend. Specific objectives include identifying factors that promote the practice, examining the employment opportunities available to these girls in Accra as well as identifying the difficulties facing stakeholders in curbing the trend. In conducting the study, random sampling technique was used to select 8 out of the 49 markets in Accra metropolis where these girls operate. Purposive sampling technique was used to select the girls for their views while the interview guide technique constituted the main research instrument. Statistical Package for Social Science (SPSS) assisted in analyzing the information captured from the field. The study found out that most of these girls are pushed down to the South for reasons including running away from forced marriages, inequalities in social amenities, the need to gather funds to establish trade back home in the North as well as coming down to look for funds to support parents and siblings back home. Challenges confronting government efforts at curbing the trend include the lukewarm attitude of the migrated girls towards getting back to classroom for formal education and vocational training. Government is also challenged with amassing funds to build decent hostel facilities necessary for ring fencing these girls for education and other life enhancement training packages. The study recommended that government makes conscious effort at educating, training and developing the skills of the migrated girls in addition to improving upon socio-economic conditions in the Northern regions. The Ministry of Health was also asked to deepen family planning awareness campaign in the North to enable parents to have children they can conveniently cater for. The teenage girls' migration syndrome is really damaging
\end{abstract}


the human capital base of the North and for that matter stakeholders must collaborate to stamp out the practice entirely.

\section{Keywords}

Teenage-Migration, Empowerment, Kayayei (Female Head Porters), Livelihood, Greener-Pastures

\section{Introduction}

In spite of efforts by central government of Ghana towards creating equal education infrastructure opportunities across the country in terms of youth development and empowerment, the drift of young teenage girls from the northern region to the south for greener pastures continues in a disturbing trend. Over the years, government has attempted to create structures for curtailing this insurgence yet, not much has been achieved. With basic and secondary school education virtually free in terms of fees, clothing, books and even one hot meal a day, one will have thought that conditions will have been attractive enough for these girls to stay up country and take advantage of the education system to broaden their personal horizon towards irking a decent living in the future. Unfortunately, most of these girls migrate to the south to find solace in such menial jobs as "kayayei" (female head porter), store girls, unskilled nannies, street hawkers with some growing up into call girls to facilitate the prostitution trade in the towns and city centers. These girls, given their low income status, are unable to rent any decent accommodation in the metropolis or municipalities and often find sleeping places in the front of shops, where they are exposed to the vagaries of the weather and also susceptible to attacks by rapists and other miscreants who predate on them to satisfy their sexual whims and caprices. Some measures certainly need to be put in place to stem the tide of migration of these girls to the South and therefore the study attempts to examine the challenges bedeviling efforts at curbing the trend so as to make appropriate recommendations.

\section{Specific objectives are:}

- To identify factors that promote North-south migration of teenage girls in Ghana.

- To examine the employment opportunities available to migrated teenage girls in Ghana.

- To identify challenges facing stakeholders effort at curbing the North-south migration of teenage girls in Ghana.

- To explore strategies for discouraging North-south migration of teenage girls in Ghana.

\section{Literature Review}

\subsection{Conceptual Review}

This segment examines the general concepts of migration and poverty allevia- 
tion as well as female head porter known as Kayayei in Ghana.

\subsubsection{Migration}

Migration describes the movement of people from one place to the other for various reasons. This notion stems from Everett Lee's Model concerning pull or push factors which motivates migration. The push factors mainly concern issues which force the individual to change his or her geographical location owing to famine, drought, conflict, inadequate job opportunities among others. The pull factors have to do with issues which force the individual to migrate owing to the need to secure higher quality of life emanating from higher job opportunities. Migration can be internal or external (international). Internal migration occurs within the country where either conflict or inequalities in socio-economic systems motivate people to move to other places. Nwajiuba (2011) notes that, internal migration is accorded less space in academia than international migration and attributes this to logistical challenges in measuring the scale of migration within countries especially in the developing world. The source explains further that globally, internal migration involves an estimated 763 million individuals. Nations with larger numbers of internal migrants are areas where conflict persists especially in the Eastern and Western Asia as well as developing economies that experience disasters relating to environments (UNFPA, 2012). Internal North to South migration also exists in Ghana for various reasons and this study attempts to investigate its persistence over the years despite various social interventions put in place by the government to curb the practice.

According to Kwankye (2012), a lot more research exists in academia on international migration than internal migrations. Excerpts from United Nations (2017) indicate in no uncertain terms the international migration worldwide increased significantly from 173 million in the year 2000 to 258 million in 2017 . According to International Organisation for Migration (2018) over 78 million people migrated to Europe in 2017 while Asia took on 80 million migrants with Africa grappling with 25 million migrants the same year. Migrations generally assist in protecting individual from hunger, danger, persecution among others and for that matter mankind will continue to live with it. The need to explore other forms of life patterns, not necessarily greener pastures, also promotes migration (Duke et al., 2013). This kind of migration is particularly prevalent within the affluent in society who can get fed up, living in one region and therefore decides to move out to a completely different jurisdiction within the same country or even another country for good. The dynamics which precipitate the North to South internal migration of teenage girls in Ghana are not too clear and for that matter this study attempts to bring out the real issues at stake for the attention of stakeholders.

\subsubsection{Poverty Alleviation and Greener Pastures}

Globally, poverty alleviation strategies especially in developing economies attempt to create structures towards ameliorating the economic hardships facing 
the underprivileged in society (Leventi et al., 2017). Such strategies often aim at creating jobs, providing more affordable houses, ICT integration, reducing cost of basic and secondary education and generally improving the infrastructural and social amenities base of the country (Collado et al., 2016). Coccia (2017) describes poverty as "a condition characterized by severe deprivation of basic human needs including food, safe drinking water, sanitation facilities, health, shelter, education and information." It is equally worth noting that inability to partake in decision making, maintenance of inequality and discrimination in gender issues, social exclusion and discrimination can, according to (Edgar et al., 2016) precipitate poverty. Certainly, poverty constitutes a complicated issue in society which need not wield one basic cause. When the economic growth of a country, which is often reflected by increment in the Gross Domestic Product (GDP) is stagnated, poverty is likely to progress. The GDP generally indicates a nation's output which can be measured in terms of total value of goods and services manufactured in that nation over a given period of time. One can therefore say that the growth in GDP value is an indication that the economy of a country is growing thereby creating the opportunity towards reducing poverty. Such opportunities often involve more job openings as a result of industrialization through Foreign Direct Investment (FDI) i.e. in the case of developing economies leading to improvement in the standard of living of the people and the process reducing poverty (Edgar et al., 2016).

Progress in economic growth in Ghana for the last 20years has been phenomenal. The country is one of the few African nations with growth rate of over $6 \%$ per annum which has been able to achieve contemporary international development goals of halving their poverty rate by the year 2015. Successes achieved in economic growth have also positioned the country on the pedestal for achieving lower-middle income status. Unfortunately, it appears this growth is not reflecting in the economic lives of majority of the people who still wallow in poverty and for that matter more work needs to be done in the areas of literacy rates, life expectancy, more job openings to ensure that the economic gains being witnessed in GDP, cascades down to the benefit of the rural folks. There is also the need to dissipate more resources towards improving such intrinsic development factors as environmental quality, freedom from oppression, poor use of leisure time among others. This way, the index on human development such as life expectancy, literacy rates can be improved to ensure higher per capita income leading to the desired fruitful and meaningful economic growth (Leventi et al., 2017). The discovery of oil raised hopes that Ghana will soon attract enough revenue to build the requisite infrastructure especially roads leading to food basket areas so as to add value to the farmers produce and the process improve upon their income base and its concomitant of standard of living. Regrettably, the oil revenue has so far not gotten to the level that should offer critical investments to support the provision of badly needed good roads for sound networking of the entire country.

A sizable quantity of foodstuffs produced in the rural areas continue to rot on 
farm lands because of bad feeder roads which have been exacerbated by recent heavy down pours as a result of change in rain fall patterns emanating from the global warming eventuality. With most of road infrastructures leading to the rural areas still in the state of despair, it will be difficult reducing poverty in the rural setting unless conscious effort is made by stakeholders towards modernizing the road network in the country especially in the hinter lands. Government of Ghana is however doing very well in terms of connecting the entire country to a national electricity grid. This has enabled more cottage industries to spring up towards adding value to a few primary produce prior to sending them to the city and town centers for further processing to finish products. Government is intensifying its ICT based digitization effort as a strategy for alleviating poverty. The monthly stipends paid to the very poor in society under the auspices of Livelihood Empowerment Against Poverty (LEAP) project is now paid directly through the mobile phone of the recipient in any corner of the country.

Membership of the National Health Insurance Scheme (NHIS), aimed at bringing quality affordable healthcare to the doorstep of the underprivileged in the country can also be renewed annually through appropriate portal on the mobile phone. Government is also maintaining one hot meal for every child in public basic schools under the Ghana School Feeding Programme. All these interventions are aimed at bringing relief to the downtrodden in society with the ultimate aim of delving a devastating blow to poverty in the country. The flagship poverty reduction project was the recent addition of free senior high school programme, without which over 100,000 qualified students could not have entered the secondary school owing to poverty levels of their parents. The Vice President, Dr. Mahamadu Bawumia was quoted as saying that owing to the free senior high school project, the affluent in society are now having serious challenges in securing house helps to assist manage their domestic chores. Most of these girls, who previously patronized such domestic work arrangement, did so as a strategy for accumulating funds to cater for their secondary education. With the secondary education being free notably no book fee, no tuition fee, no boarding fee etc. parents have no option but to send their adolescent wards to school. A student loan scheme has also been instituted to cover tertiary education and this will assist students from deprived homes to access university education without difficulty. With all these policies on board aimed at reducing poverty in the country and ensuring unimpeded access to all strata in education, the country is likely to produce the kind of human capital needed to drive its developmental agenda. Notwithstanding these government interventions, the internal North to South migrations of teenage girls in Ghana continues unabated. Something is certainly not working properly which is worth investigating. This is the thrust of the study.

\subsubsection{The Concept of Female Head Porters (Kayayei) in Ghana}

For some time now, Ghana continues to experience intra-national mobility especially the rural urban migration as a result of inequality in industrialization, 
urbanization and modernization of the country. The exodus involves adult and under-aged female people who move from Northern part of Ghana to Accra and work under very trying conditions (Wilson \& Mittelmark, 2013: p. 1). According to Alston (2007) a noticeable rise in poverty within the groups of women in the Northern region account for such drift of people and it is as a result of social policy failure. The source goes on to indicate that government is giving too much attention to globalization which has brought in its wake neoliberal policies that continue to worsen the plight of the improvised in the Northern and other areas of the country. It is regrettable that studies by Jehu-Appiah et al. (2011) indicate that $80 \%$ of the population within the five northern regions are poor with nearly 70\% extremely poor. Awumbila and Ardayfio-Schandorf (2008) also found out that adult illiteracy rate and child under-nutrition are most pronounced in Ghana in these five northern regions. Such indicators all have serious implications for both international and national policies directed towards reducing social exclusion and inequalities (Yeboah, 2010). Obviously, there is the need for a concerted effort at addressing these uncomplimentary social policy failure indicators through renewed bespoke policy interventions.

The term Kayayei was coined in the brisk business centers of Ghana notably Accra, Techiman and Kumasi were a lot of cargo trucks discharge commodities which need to be relocated and as in Ghana and other West African countries, such processes involve carrying on human head by these girls and while the boys use trucks and wheel barrows to break the bulk into chewable units for the retailers and other intermediary vendors. As indicated earlier, these Kayayei or female head porters mainly emanate from the five northern regions of Ghana notably Upper-West, Upper-East, North East, Savanna and Northern region. Although the two big cities in Ghana, Kumasi and Accra constitute the eventual destination for the Kayayei, some do not have the means of doing the straight journey and for that matter stop over at Techiman where they operate as Kayayei for some time, gather enough money and then move on to Kumasi or Accra. The whole concept of Kayayei is predicated on livelihood which Oxford Dictionaries (2018) defines as "a means of securing the necessities of life". Researchers like Ellis and Freeman (2004) have all employed this concept in analyzing the drift from rural to urban areas as a result of poverty.

\subsection{Theoretical Review}

\subsubsection{Theories of Regional Development}

The theory of regional development is predicated on the fact that every government must strive to reduce socio-economic disparities within the geographical areas of the country so as to support the overall development of the entire living systems within that country (Coccia, 2009, 2017). The source continues that most developing economies wield geo-economic space where regional disparities abound leading to unemployment, income inequality, violent crime, poverty and social issues. The Northern regions of Ghana provide a shining example of this situation where regional economic disparities really exist thereby motivating 
teenage girls and others to embark upon internal migration to the South in such of greener pastures to enhance their livelihood. The people in the North of Ghana are predominantly farmers and nomads and depend upon the rainfall for their produce basically grains, root crops, shear nuts, vegetables among others. With global warming disrupting rainfall patterns, most farming communities are finding it extremely difficult to make enough money from their farming efforts.

Central government, through its policy of One village One dam is trying to assist irrigate farms so as to reduce the existing practice of rain fed agriculture yet, not much has been achieved. The youth therefore find solace in travelling down South to seek greener pastures to strengthen their livelihood as a strategy for developing themselves. Development, in this context has been defined by Perroux (1955: p. 308) as "a selective, cumulative process which does not appear everywhere at the same time but becomes manifest at certain points in space with variable intensity."

Analyzing this definition gives credence to the need for the teenage girls to migrate from the North where "selective cumulative" processes are lacking to the South where these are available in "variable intensity". In his argument Perroux (1955: p. 309) also asserted that growth does not happen everywhere within the same time with similar magnitude of intensity but growth comes at particular "spatial point or poles of growth with varying intensity of socioeconomic interaction; after that, it these poles spread economic activities along various channels, generating different effects on growth of regional and national economic systems." The regional development theory therefore enjoins countries especially those in the developing category to intensify efforts towards creating equal opportunities within all city, towns and villages within their jurisdictions.

\subsubsection{Growth Pole Theory}

The theory of growth pole, developed by Jacques Raoul Boudeville, establishes the fact that when cluster of industries are scattered within a nation, growth often precipitate and the citizenry are usually exposed to seemingly equal opportunities for accessing jobs irrespective of where one is located. The Kayayei scenario is a shining example of a situation where industries are concentrated only in the Southern zone thereby keeping the Northern sector deprive or such manufacturing concern and the process diminish opportunities for accessing jobs by the citizenry. The growth pole theory therefore has to be taken serious by nations in the developing economy category. This way, electricity supply and other industry friendly infrastructure will be extended to all corners within the country so as to streamline difficulties for establishing factors in certain deprived areas of the country. The incidence of Kayayei in Ghana would have been reduced drastically if factories did abound in the Northern regions of Ghana.

In the opinion of Coccia (2019) an essential element within the growth pole concept is the cluster of industries or firms which are strongly related through some kind of input/output linkages. This will certainly facilitate the management 
of supply chain activities surrounding these closely related firms and industries and also go a very long way to reduce cost thereby enabling the companies to produce high quality goods at affordable prices. In developing the concept of growth pole, Jacques Raoul Boudeville examined closely the way firms and industries were expanding at close locations and influencing the development of infrastructure, social amenities at a rapid rate and also improving upon the propensity of the citizenry to access good jobs. He therefore concluded that for effective development to take place, firms and factories must spring up closely and simultaneously in various parts of the country so as to ensure a corporate development of that nation. The growth pole theory makes it mandatory for the industrialized nations to assist with those in the developing category with foreign direct investment as well as technical assistance so as to enable them judiciously apply the imported resources for the intended purposes. Although aggregation of firms and industry constitute an important element in organizational efficiency, Coccia (2009) notes that, it is not the key element that drives regional growth. This presupposes that growth pole theory and regional development theory can be compared and contrasted in content. Notwithstanding, they all speak of structures being created to enhance fair spatial development of countries.

\subsection{Empirical Review}

The empirical review examines internal migration and its impact in Asia notably China and India as well as in Africa where the searchlight has been on a situation in Kenya and Nigeria.

\subsubsection{Asia}

\section{1) China}

It is a common knowledge that the Chinese success story in the manufacturing sector within the past three decades can be inexplicably linked with the migration of workers within the country yearning for subsistence income to manufacture goods for exports (Cai et al., 2011: p. 18). The source continues that the entire stock of rural migrants in terms of labourers, which was estimated to be about 155 million in 2010, was the backbone of the Chinese export drive which commenced in the mid-1990s. Honestly, export epicenters in China notably Dongguan and Shenzhen are reported to have between $70 \%$ and $80 \%$ of the labour force being migrants (Chan, 2007). It is needless to indicate that rural urban migration played a pivotal role in China's urbanization framework. Since 1979, Chan (2010) reports that Chinese urban population grew by about 440 million to the level of 622 million as at the case of 2009. The source further indicates that out of the 440 million migrated urban population, 340 million emanated from net migration as well as urban reclassification.

From the foregoing, it is abundantly clear that internal migration in China really accounted for the rapid industrialization of that country. The immigrants were not too expensive in terms of HR cost as compared to the indigenes and 
this enabled operation cost to remain within acceptable levels thereby helping the companies to sell their product at highly competitive prices. In spite of the key role migration played in China's industrialization, migration trends in the country according to Liu and Chan (2001) continue to be misinterpreted thereby creating distortions in figures in terms of the quantum of migrants in terms of migration stock and flow. Naturally, migration is not easy to measure and this is complicated in China by the way the concept is defined which is different from those prevailing in other nations (Chan 2007). This source adds that analyzing migration in China comes with further difficulties in respect of certain institutional arrangements and system of migration and population management as well as the statistical approach in conducting the measurement. Researchers in United Nations once referred to Chinese as "floating population", the largest group of internal migrants in China, "statistically invisible" (UNDP, 1999). Other researchers notably Roberts (2002) also had difficulty finding the "invisible residents" in China and such problems have disrupted the ability to effectively analyze not only migration in China but also the country's urbanization, industrialization and other related matters. Owing to the aforementioned problems, an appropriate arrangement was established to assemble the different migration statistics properly so as to enable researchers make meaningful assessment of the numbers and establish accurate inferences in their comparisons.

Perhaps it might be worth indicating that for any meaningful assessment of Chinese internal migration to be conducted, one must begin by understanding the system of hukou and how it influences migration. A well-established fact is that Chinese migration is highly scrutinized and has been an essential aspect of the strategy for national industrialization (Chan, 2009). Citizens wanting to effect change in residence permanently are expected to secure permission for hukou change from authorities within their locality (Wang, 2005). Residents in urban areas who wish to embark upon permanent change in residence i.e. changing hukou residence in the same city or urban area to a new address in the same town, are allowed in the same way rural residence moving within rural areas, citing family or marriage reason. Notwithstanding, permanent moves i.e. crossing town or city and city boundary are seriously regulated and require permission by a more serious public security authority. Such approval is often farfetched unless there is a very good reason for moving across cities which must be in consonance with state policies on migration. In recent past in China, the indigene concept of internal migrants i.e. hukou change has been applied in state labour recruitment and farmland expropriation. This same hukou tool continues to be employed to ensure fair tariffs in terms of rent for urban housing market as well as the recruitment of seasoned professional for various purposes (Chan, 2009). Generally, it is increasingly becoming very difficult in China for an ordinary citizen to migrate either from rural to urban or vice versa, since government thinks job opportunities have been equally distributed across the Chinese "federation" except in very few instances where the necessary approval ought to 
be sought from relevant state agencies (Wang, 2005).

\section{2) India}

India, like other developing economies has gone through tremendous demographic change since the early 1970s (IIPS \& ICF, 2017). The source explains further that during this period, the rate of fertility has continue to decline as a study rate from as high as 6 in the early 1970s to almost 2.2 by the end of 2015 . Life expectancy rate has also improved significantly from 50 years around 1970 and 1975 to 68 years by close of 2015 (Census of India, 2017). Consequently, the country experiences a young population with nearly $60 \%$ of citizens being the change range of 15 to 59 which gives a median age of around 24 years as per the census organized in 2011. In terms of population, India as at the end of 2020 is around 1.38 billion and the second most populous nation in the world yet in terms of geographical area, it is the seventh largest country. Urbanization remains relatively low at $31.1 \%$ despite significant improvement in demographic transition. This, according to Bhagat (2005) stems from a restrictive definition of the constituent of an urban area together with relatively low net rural to urban migration's contribution to the growth of the country. This seems to suggest that migration plays a limited role in redistribution arrangements of the population from the rural state to urban centers in the country (Bhagat \& Mohanty, 2009). This is to say that rural to urban migration in India has not had any tremendous impact on urbanization of the country although the country wields a history of movement of people internally in the country (Zhu, 2000).

In partitioning the country i.e. after independence in 1947 to current India and Pakistan resulted in coerced displacement of nearly 14 million people with 7 million people being displaced on each side of the two borders (Visaria, 1969). Internal migration in India precipitated from the tremendous growth of industries and commerce around cities with ports notably Madras (Chennai), Bombay (Mumbai) and Calcutta (Kolkata). According to Bhagat and Jones (2014) these three new commercial centers together with New Delhi, gave special impetus towards the growth of regional economies and this triggered large volumes of inter-regional migration arrangements within the country. It was not surprising that a good number of small and medium-sized industries begun to flourish in these four cities which depended on semi-skilled and unskilled labour which came from the countryside. For instance, around the 1970s Raza and Habeeb (1976) indicate that large quantum of employees in the Calcutta jute factories were natives of underdeveloped towns like Odisha, Uttar Pradesh, Andhra Pradesh and Bihar. Also in Mumbai where a good number of textile factories abound, large segment of workers were recruited from less endowed districts within the state of Maharashtra (Bhagat \& Jones, 2014). This clearly exhibited the regional inequalities in job opportunities thereby triggering internal migration (Raza \& Habeeb, 1976). It can therefore be said that in India, economic disparities within the regions continue to motivate people to migrate into commercial centers i.e. cities of Kolkata, Delhi, Mumbai and Chennai. 


\subsubsection{Africa}

\section{1) Kenya}

Internal migration in Kenya continues to be in consonance with the widely accepted fact that inequalities in socio-economic system precipitate such rural-urban movement of people. Early writers on internal migration in Kenya such as Harris and Todaro (1970); Cole and Sanders (1985) have shown beyond reasonable doubt that migration from rural areas to urban towns and cities emanate from brighter job opportunities in these areas where they could access higher wages. Studies by Zhu (2002); Schultz (1982) also indicates unequivocally that expected income constituted an important determinant of rural to urban migration in Kenya. Other studies also indicated that rural area migration in Kenya was motivated by per capita land possession in the rural areas (Galeano, 2009). The latter notes that inequality in land allocation somewhat suppresses agricultural income for a good number of rural house unit and this pushed them into other areas in such of larger land segment to cultivate for better livelihood. In the opinion of Oyvat (2016), the new migrant settler enters into some land tenure settlement arrangement with the land owner to ensure a mutually beneficial tenure system. The source also found out that rural dwellers born at areas with relatively high land inequality arrangements often experience lower per capita land which reflected in lower income from agricultural produce and such people had higher propensity of migrating to other areas where they could secure bigger farm lands to irk their living. This kind of migration can be described as a rural-rural migration which has being ignored in academia in favour of rural-urban migration (McCormick \& Wahba, 2005). The latter maintains that migration for greener pastures is not only from rural to urban but also from rural to rural in search for better farming opportunities. The source also noted that studies often treat urban destinations as being homogenous yet cost of living can be very high in certain areas which often swallow up almost the entire income of the migrants and the process could even make them worse of in terms of economic independence.

In Kenya for instance, cost of living in these four commercial centers Eldoret (Uasin Gishu), Kisumu, Mombasa and Nakuru are so high that some migrants avoid working in such cities (Mudege \& Zulu, 2011). As a result, any framework that attempts to explain rural-urban migration in Kenya in terms of expected income levels can be said to be a weak one judging from the fact on the ground (Archambault et al., 2012). Moreover, the source continues that the age of the rural dweller could help reduce the rural to urban migration but had very little effect on the rural to rural migration. This stems from the fact that an older person may not come to the South i.e. rural to urban migration but out of their necessity, may move to another rural area in search of better fertile and bigger acreage of land to enhance his or her farming activities for survival purposes. Mudege and Zulu (2011) also found out that in Kenya, distance to the capital Nairobi could significantly influence migration decision except those who are poised to migrate to central or metro Nairobi. During pre-independence era, the 
colonial masters established modern farms in the urban areas and required cheap labour to work on these farms. Agencies were therefore established across the country towards conscripting and migrating the able bodied youth and men from the hinterlands to be engaged on the colonial masters farms. Migration was therefore restricted to the male population while the women were left behind in charge of their households. Well after independence when the migration restriction was lifted, the male migration notion had been well integrated in the Kenyan culture and therefore the women population hardly migrated in search of greener pastures (Kitching, 2011).

\section{2) Nigeria}

With respect to internal migration in Nigeria, literature quickly mentions South-East Nigeria which constitute the Southern Nigerian lying east of the River Niger and moves a bit to the South of the River Benue. It is essentially an agriculture zone with very fertile land and enviable rainfall patterns. However, according to Nwajiuba (2011: p. 8), the available land is largely disproportionate to the socio-economic survival of the quantum of residents. Although the land is only 8.5 percent of the entire land size of Nigeria, it accommodates 25 percent of the population of the country (Olajide, 2013). The size of the land even shrinks further when one considers only the available arable land for farming purposes. The local economy can therefore be said to be mainly agrarian with the major sustainable export crop being oil palm. It is not surprising that this segment of Nigeria used to be adequately self-sufficient in the production of such local staples as yam, maize, fruits, plantain, cassava, various vegetables and cocoyam (Okorie, 2002). Unfortunately, though they were employing small arable farm lands, farming was conducted using the purely traditional tools which, given the growing population, could not produce enough to sustain the inhabitants. Consequently, socio-cultural factors, macro-economic factors and political factors precipitated the drift of the youth and other abled bodied to other parts of Nigeria in search of greener pastures to irk more comfortable socio-economic lives Nwajiuba (2011: p. 8). As indicated earlier, the capacity of the land cannot sustain the labour potential of the rural population and in such circumstances, it is only logical that the oversupply of labour will trigger increasing rural urban migration. According to Akinsanmi (2005: p. 22), the average farm family employs lower than $50 \%$ of its estimated "labour potential of 960 man-days" and this presupposes that rational human beings must make a move towards marketing their skills and energies elsewhere thereby promoting rural-urban migration in that enclave of Nigeria where the migration rate is estimated to be the highest in the entire country. As a consequence, there was a continuous drift of human resource from "the primary production sector of Agriculture to other areas such as 'spare parts trading' in urban areas across the nation" (Akinsanmi, 2005: p. 22). According to Nwajiuba (2011: p. 10), only about $22 \%$ of the native population are residing in the South-East of Nigeria while $78 \%$ reside outside their homes. Another factor which influenced rural to urban migration according to (On- 
weagba \& Chukwu, 2011) had to do with the poor state and slow pace of infrastructure development in the South-Eastern area, as evidenced by poor health facilities, poor roads and poor water supply systems. At the same time, other towns and cities within the Nigerian federation had better share of infrastructural facilities, social amenities and more decent job openings. Such absence of requisite life enhancing systems in South-Eastern Nigeria constituted the pull and push factors for the youth to migrate.

The afore-discussed empirical review presented the internal migration situation and circumstances in Asia notably China and India as well as part of Africa like Kenya and Nigeria. Not much is known about the factors that drive internal North to South migration in Ghana and for that matter this study attempts to fill this gap.

\section{Research Methodology}

\subsection{Study Area}

The Accra business region constituted the study area which incidentally happens to be the capital city of the country. Recent population and housing census uncovered the number of residents to be 5.4 million being the most populated enclave in the country. As the national capital, it is not surprising that most of the headquarters of public institutions, formal sector corporate institutions like the banks, insurance companies, mining companies, multinational establishments, foreign missions, world-class NGOs etc., are all situated in this region. The socio-economic landscape is therefore very brisk and market sectors are equally booming. The study took place within 8 markets of the Accra business region namely Makola market, Agbogboloshie Market, Dansoman Market, Kaneshie Market, Osu Market, Mallam Market, Abeka Market, Anyaa Market where these girls mostly ply their trade as kayayei or female market porters. It is worth noting that these are the main market centers with adequate facilities for receiving larger trucks and buses which convey the teenage girls from the North to the South and therefore has the propensity for facilitating interviewing of the girls, the drivers as well as other stakeholders. Each of these markets has between 30 and 40 head porters (Kayayei) who had migrated from the North thereby giving us a population size of 290 .

\subsection{Sampling Technique}

Each of the eight markets was seen as a group or a stratum from which random sampling technique was used to select the girls for their views on the objectives of the study. The use of the random sampling was motivated by the fact that the kind of information being solicited could come from any of the migrated girls. It can therefore be said that stratified random sampling technique aided in the selection of study respondents. Purposive sampling technique however assisted in approaching the truck drivers as well as leaders of the Kayayei groups directly for their views. 
Most of the girls speak Hausa, Kusasi, Mamprusi which are languages spoken in the North as against the typical Akan, Ga and Ewe languages used in the South. The research team therefore had to hire interpreters from among the girls who have been around for 3 to 6 years and for that matter could understand both Southern and Northern languages. Since some of the markets are relatively bigger than others, care was exercised to ensure that the sample from each market reflect the size of the kayayei in those trading places. In calculating the minimum sample size of 168 , the Slovin's formula i.e. $n=N /\left(1+\mathrm{Ne}^{2}\right)$ where $n$ is the sample size, $\mathrm{N}$ is the population size 290 and e i.e. the margin of error of $5 \%$ was very helpful.

Table 1 reflects the age distribution of respondents and indicate that out of 168 migrated teenage girls of Ghana, 17 (10.1\%) are aged between 9 and 12 yrs while $32(19.04 \%)$ also have their ages ranging from 13 to 15 yrs. Fifty-four (32.1\%) migrated girls are of the ages between 16 and 18 yrs while 65 (38.69\%) also have their ages within the age of 17 and 19 yrs. Most of these girls spend 3 to 5 years down South doing menial jobs and return to North with their "wealth" to help cater for their parents, siblings and other responsibilities.

\subsection{Research Instrument}

Since most of these teenage girls had abandoned formal basic education without completing primary 6 , they could hardly read and write and for that matter it was logical to employ the interview guide as the main research instrument. The

Table 1. Reflect the sample distribution.

\begin{tabular}{|c|c|c|c|c|c|c|}
\hline Market & $\begin{array}{c}9-12 \\
\text { yrs }\end{array}$ & $\begin{array}{c}13-15 \\
\text { yrs }\end{array}$ & $\begin{array}{c}16-18 \\
\text { yrs }\end{array}$ & $\begin{array}{c}17-19 \\
\text { yrs }\end{array}$ & $\begin{array}{l}\text { Total } \\
\text { Freq. }\end{array}$ & $\%$ \\
\hline $\begin{array}{c}\text { Makola } \\
\text { market }\end{array}$ & 2 & 7 & 10 & 14 & 33 & 19.64 \\
\hline $\begin{array}{c}\text { Agbogboloshie } \\
\text { Market }\end{array}$ & 3 & 7 & 12 & 15 & 37 & 22.02 \\
\hline $\begin{array}{c}\text { Dansoman } \\
\text { Market }\end{array}$ & 2 & 5 & 7 & 11 & 25 & 14.88 \\
\hline $\begin{array}{c}\text { Kaneshie } \\
\text { Market }\end{array}$ & 2 & 4 & 8 & 7 & 21 & 12.50 \\
\hline Osu Market & 2 & 3 & 5 & 6 & 16 & 9.52 \\
\hline $\begin{array}{l}\text { Mallam } \\
\text { Market }\end{array}$ & 2 & 2 & 4 & 4 & 12 & 7.14 \\
\hline Abeka Market & 2 & 2 & 5 & 4 & 13 & 7.75 \\
\hline Anyaa Market & 2 & 2 & 3 & 4 & 11 & 6.55 \\
\hline Total & 17 & 32 & 54 & 65 & 168 & 100 \\
\hline
\end{tabular}

Source (Researcher's Estimation, 2022). 
instrument was fragmented into five sections with the first devoted to demographic features of the respondents. The remaining four sections sought to solicit views for addressing the four specific objectives of the study.

\subsection{Data Collection and Analysis Strategy}

An informal visit was carried out two months before the survey with the view to exploring strategies for conducting the study successfully. This entailed getting involved with the leaders from the various migrated teenage girls' communities in the markets to prepare the grounds for the study. After seeking the consent of their leaders and agreeing on the time for conducting the interviews, the research team including interpreters visited these underprivileged girls in the evenings between $7 \mathrm{pm}$ and $9 \mathrm{pm}$ and on Sundays when most of the market places did not open for brisk business. Some of the girls requested for compensation in respect of time spent in cooperating with the study to which the team readily offered GHC 20.00 (USD3.30). It came out that some of them carried babies which were conceived while in the South.

Generally, the interviewing atmosphere was calm except a few instances where rain storm in the evening displaced some of the girls who apparently had nowhere to sleep thereby exposing the dangers and trying conditions under which they operate. The team members used their phones in recording most of the responses which were interpreted by the hired translators. Frequency tables were then generated from the captured responses, fed into a Statistical Package for Social Science (SPSS) version 21 software.

\subsection{Validity and Reliability}

On validity of the study, the researcher is of the conviction that when different set of scholars were given same interview guide to conduct this study, the results will be the same as those presented in this report. With respect to the reliability of the study by employing the Slovin's formula to calculate the minimum acceptable sample of 168 for the study, one should think that this sample is representative enough to generalize the findings of the study.

\subsection{Ethical Consideration}

Initially, the girls thought the security apparatus were behind the study in an attempt to round them up and forcibly return them to the North. The team did well to debunk this notion and explained to them it was purely for an academic purpose which had the propensity of attracting international attention to their plights and possibly bring in assistance to address the inequalities in the North as well as resettling them properly to irk a more decent living. The respondents therefore volunteered to cooperate with the study with no one being coerced or placed under duress to answer questions in any particular direction. No embarrassing questions were asked and respondents who did not wish to answer particular questions were permitted to enjoy their pleasure. In terms of ethics there- 
fore, the study is highly upright.

\section{Findings}

This segment presents result in respect of responses obtained from the field study. It begins with the demographic features of the respondents prior to indicating the views on the four specific objectives of the study.

\subsection{Demographic Features}

Presented here in respect of demographic features are age range, academic background, vocational training, number of other girls helped to migrate, marital status and number of children.

\subsubsection{Academic Background}

It came out from the study that $86(51.2 \%)$ respondents abandoned formal education at lower primary level while $70(41.7 \%)$ respondents did not start school at all. Twelve (7.1\%) respondents did move on to upper primary but failed to complete primary 6 . The trend indicates that $98(58.3 \%)$ respondents are school dropouts and for that matter some kind of effective adult education program could possibly bring them back to the classroom given the right motivation or incentives.

\subsubsection{Vocational Training Status before Migration}

The study was of the opinion that the 70 migrated girls who did not start school might have been engaged in one form of educational training or the other or helping with the family's farming business. It came out that out of this number $28(40 \%)$ were indeed helping with the family's farming business when they were lured by friends to travel down South for greener pastures. Again, out of the 70 that did not start school, 19 (27.1\%) respondents were under-apprenticeship learning such trades as beads making, dressmaking, hair dressing, catering, soap making and other trades when they deserted the course and came down for greener pastures. It also came out that 17 (24.3\%) respondents had previously left apprenticeship mid-stream and playing around in the North when they were exposed to the idea of seeking greener pastures in the South. A small number i.e. $6(8.6 \%)$ of the migrated girls had completed vocational training apprenticeship in the North but had no money to establish their trade and for that matter the only option exercisable was migrate to the South in such of funds to commence business in the North.

\subsubsection{Number of Girls Influenced to Migrate to the South}

The informal discussion with the girls came up unequivocally that they keep sending money to their friends and siblings back home in the North to also migrate to the South to improve upon their living conditions. The study therefore decided to investigate the quantum of girls who are engaged in such "assistance to migrate" endeavours. It turned out that as many as 102 (60.71\%) migrated 
girls have helped either their sisters or friends also to come to the South to enjoy better lives. This clearly indicate the wide spread nature of the migration business and calls for immediate attention in order not to destroy the human capital base of the North.

\subsubsection{Marital Status before Migration}

The study noted with surprise that girls, as early as 13 years had already been betrothed to men for marriage and that their parents received cows as dowry. Most of these potential husbands already had 2 or 3 wives but were seen in the north as rich men who could take care of the girls. Poverty therefore motivated such parents in "selling" their daughters into marriage in exchange for cows. The study indicated that $43(25.6 \%)$ girls were involved in such early marriage arrangements while 11 (6.5\%) who were between 16 and 19 years are already young widows with their husbands passing away soon after their marriage arrangements were concluded. Such girls, out of economic pressures had to come down to secure economic freedom. Twenty-two (13.1\%) migrated girls aged between 16 and 19 years indicated that they are married and authorized by their husbands to seek greener pastures in the South with the view to helping the men to cater for the other senior wives and children. Some of them visit their husbands in the North twice in a year.

\subsubsection{Future Personal Plans of Migrated Girls}

The study investigated the future plans of these girls and it came out that out of the 168 respondents, 50 (29.76\%) wanted funds to go back to establish businesses. Forty (24.4\%) migrated girls are down to the South to make money and back to assist their husband to manage the other wives and children more effectively. In the views of $35(20.83 \%)$ migrated girls, life in the South is more pleasurable and for that matter they are here to make money and settle. In the case of 21 (12.5\%) migrated girls, going back home means returning to honour forced marriages and for this reason they remain in the South to irk their living. On the part of $21(12.5 \%)$ migrated girls, life in the South is pleasurable and they are yet to make up their minds as to what to do with the lives.

\subsection{Objective One on Factors that Promote North to South Migration of Teenage Girls in Ghana}

Presented in this segment are the results on objective one which examines the factors that promote North to South migration of teenage girls in Ghana.

\subsubsection{Reasons for Migration of Teenage Girls in Ghana}

Shown in Table 2 are reasons for the internal migration of teenage girls from North to South of Ghana.

Table 2 presents results on the reasons why teenage girls leave North to the South of Ghana in search of greener pastures. Ranking first with mean score of 3.669 , standard deviation of 0.886 and variance of 0.785 was the statement that "I was forced into marriage to be a third wife". Another factor that promotes 
Table 2. Frequency table on migration of teenage girls.

\begin{tabular}{lccccc}
\multicolumn{1}{c}{ Statement } & N & Mean & $\begin{array}{c}\text { Std. } \\
\text { Dev. }\end{array}$ & Variance & Rank \\
\hline $\begin{array}{l}\text { I was forced into marriage } \\
\text { to be a third wife }\end{array}$ & 168 & 3.669 & 0.886 & 0.785 & 1 \\
$\begin{array}{l}\text { After learning trade, no } \\
\text { means of establishing myself }\end{array}$ & 168 & 3.518 & 1.037 & 1.075 & 2 \\
$\begin{array}{l}\text { Parent are planning to } \\
\text { curtail my education in } \\
\text { favour of marriage }\end{array}$ & 168 & 3.427 & 0.777 & 0.558 & 3 \\
$\begin{array}{l}\text { Friends who go to the south } \\
\text { often return with enviable } \\
\text { personal effects }\end{array}$ & 168 & 3.219 & 1.019 & 1.038 & 4 \\
$\begin{array}{l}\text { Living conditions in the } \\
\text { North are poor, insufficient } \\
\text { food and clothing }\end{array}$ & 168 & 3.165 & 1.294 & 1.673 & 5 \\
$\begin{array}{l}\text { No electricity in some parts } \\
\text { and life is boring in the }\end{array}$ & 168 & 2.896 & 1.029 & 1.059 & 6 \\
$\begin{array}{l}\text { North } \\
\begin{array}{l}\text { My parent have too many } \\
\text { children and cannot cater } \\
\text { for us all }\end{array}\end{array}$ & 168 & 2.758 & 1.123 & & \\
\end{tabular}

Source (Field Data, 2022).

teenage girls migration was the notion that "after learning trade, no means of establishing ones self in the North". Coming third in ranking was the statement that "parents are planning to curtail my education in favour of marriage". The response that "friends who go to the south often return with enviable personal effects" came fourth in ranking. The fifth ranking was the idea that "living conditions in the North are poor, insufficient food and clothing". A further factor was the statement "no electricity supply in some parts and life is boring in the North". The sixth ranking was the response that "my parents have too many children and cannot cater adequately for all of us".

\subsubsection{The Methodology for Migrating to Accra from the North}

Featured in Table 3 are the results of how teenage girls migrate from the North to Accra to enjoy seemingly better living systems.

Table 3 essentially features the methodology adopted by the girls for funding the trip to Accra. The first ranking with mean score of 3.416, standard deviation of 1.109 and variance of 1.008 was the statement that "I collected money from friends for the transportation to Accra". This indicates that friends often support their colleagues to migrate to the South. Coming second in ranking was the response that "I stole money from parent/family to come to Accra". This indicates 
Table 3. Frequency table on how teenage girls move to Accra.

\begin{tabular}{lccccc}
\multicolumn{1}{c}{ Statement } & N & Mean & $\begin{array}{c}\text { Std. } \\
\text { Dev. }\end{array}$ & Variance & Rank \\
\hline $\begin{array}{l}\text { I collected money from } \\
\text { friends for the journey to } \\
\text { Accra }\end{array}$ & 168 & 3.416 & 1.109 & 1.008 & 1 \\
$\begin{array}{l}\text { I stole money from } \\
\text { parents/family to come } \\
\text { to Accra }\end{array}$ & 168 & 3.391 & 0.988 & 0.976 & 2 \\
$\begin{array}{l}\text { A friend who came from } \\
\text { Accra to the North loaned } \\
\text { me some money for }\end{array}$ & 168 & 3.306 & 1.036 & 1.074 & 3 \\
transport to Accra & & & & & \\
$\begin{array}{l}\text { I stole money from my } \\
\text { husband as third/fourth }\end{array}$ & 168 & 3.251 & 1.453 & 2.112 & 4 \\
$\quad$ wife to Accra & & & & & \\
\hline $\begin{array}{l}\text { A boyfriend gave me money } \\
\text { to travel to Accra }\end{array}$ & 168 & 3.112 & 1.195 & 1.428 & 5 \\
$\begin{array}{l}\text { My parents supported me } \\
\text { with funds }\end{array}$ & 168 & 2.796 & 0.909 & 0.826 & \\
\hline
\end{tabular}

Source (Field Data, 2022).

that some girls were pushed into the act of stealing in order to facilitate their migration to Accra. The idea that "a friend who came from Accra to the North lent me money for transport to Accra” came third in ranking. This also clearly shows that those who are already in Accra sympathize with those left behind and often assist them in joining the migration exercise. Ranking fourth was the statement that "I stole money from my husband as third/fourth wife to Accra". Girls who are unhappy with the parents' parochial interest in marrying them out as third or fourth wives often devise ways of getting out of such relationship. "A boyfriend gave me money to travel to Accra is another way that helps teenage girls in migrating to Accra" came fifth with mean score of 3.112, standard deviation of 1.195 and variance of 1.428. Coming sixth in Table 3 is the response that "my parents supported me with funds". This shows that parents also facilitate the North to South internal migration.

\subsubsection{Sleeping Places of Teenage Girls in Accra}

Depicted in Table 4 are the findings on the places where teenage girls from the North sleep while in Accra for a menial job.

Table 4 features findings on the sleeping places of teenage girls who migrated from the North to Accra in search of greener pastures. Ranking first with mean score of 3.673, standard deviation of 1.029 and variance of 1.059 was the statement they sleep "in front of some shops at where I work". Most of the shops in 
Table 4. Frequency table on sleeping places of migrated teenage girls.

\begin{tabular}{lccccc}
\multicolumn{1}{c}{ Statement } & $\mathrm{N}$ & Mean & $\begin{array}{l}\text { Std. } \\
\text { Dev. }\end{array}$ & Variance & Rank \\
\hline $\begin{array}{l}\text { In front of some shops at } \\
\text { where I work }\end{array}$ & 168 & 3.673 & 1.029 & 1.059 & 1 \\
$\begin{array}{l}\text { We sleep in a wooden } \\
\text { structure at the road side }\end{array}$ & 168 & 3.610 & 1.037 & 1.075 & 2 \\
$\begin{array}{l}\text { We sleep in the container } \\
\text { shop where we work }\end{array}$ & 168 & 3.564 & 1.294 & 1.673 & 3 \\
$\begin{array}{l}\text { Six of us pulled resources to } \\
\text { rent a single room }\end{array}$ & 168 & 3.502 & 0.985 & 0.971 & 4 \\
\hline
\end{tabular}

Source (Field Data, 2022).

Accra business center i.e. Okaishie have adequate spaces in front where the trader displays the wares to enhance visibility. At the close of work the wares are returned into the store house thereby leaving such places empty. The market head porter girls then use such places as their sleeping booths. The response that "we sleep in a wooden structure at the road side" came second in ranking. Some construction sites have wooden structures in which building equipment are locked up while construction is in progress. Such wooden structures are usually abandoned when work is stalled thereby paving the way for these migrated girls to habitat as dwelling enclaves. Coming third in ranking was the statement that "we sleep in the container shop where we work". Imported consignment often comes in containers and when the goods are dislodged, the containers are often left empty not too far from where the dislodgements were made. These girls therefore take advantage of their relationship with the shop owners and sleep in these metal enclosures. Ranking fourth with mean score of 3.502, standard deviation of 0.985 and variance of 0.971 was the response that "six of us have joined money to rent a single room". Some of these girls who have been in the trade for some time often see the need to live in better accommodation facilities and therefore put funds together and rent single rooms close to where they operate so as to avoid paying transport cost to their work places.

\subsubsection{Constraints Associated with Sleeping Places of Migrated Girls}

Displayed in Table 5 are the findings on the problems teenage girls encounter while sleeping in their mid-shift "apartments".

Indicated in Table 5 are the findings on the problems teenage girls face while sleeping at their ramshackle places. Coming first in ranking is the response that "boys often raid our sleeping places with knives to collect our monies". The market places are also filled with street boys who prey on these girls and sometimes succeed in forcibly taking money from them at night. The second ranking is the fact that "some of the attackers in the night often rape us when we do not have money, at gun point". This is a disturbing finding which ought to gain the attention of the authorities because every citizen needs protection. Ranking third 
Table 5. Frequency table on the problems faced by teenage girls while sleeping.

\begin{tabular}{|c|c|c|c|c|c|}
\hline Statement & $\mathbf{N}$ & Mean & $\begin{array}{l}\text { Std. } \\
\text { Dev. }\end{array}$ & Variance & Rank \\
\hline $\begin{array}{l}\text { Boys often raid our sleeping } \\
\text { places with knives to collect } \\
\text { our monies }\end{array}$ & 168 & 3.503 & 1.043 & 1.088 & 1 \\
\hline $\begin{array}{l}\text { - Some of the attackers in the } \\
\text { night often rape us when we } \\
\text { don't have money to give } \\
\text { them at gun point }\end{array}$ & 168 & 3.392 & 1.195 & 1.428 & 2 \\
\hline $\begin{array}{l}\text { - When it rains, those of us } \\
\text { who sleep in front of shops } \\
\text { are rendered "homeless" }\end{array}$ & 168 & 3.221 & 1.003 & 1.007 & 3 \\
\hline $\begin{array}{l}\text { Because some of us sleep in } \\
\text { front of shops, we have to } \\
\text { wake up as early as } 4 \text { am } \\
\text { and this often affect our } \\
\text { health }\end{array}$ & 168 & 3.224 & 1.114 & 1.242 & 4 \\
\hline $\begin{array}{l}\text { When we have stomach } \\
\text { upset in the night, it is } \\
\text { difficult to locate a } \\
\text { comfortable place of } \\
\text { convenience in good time }\end{array}$ & 168 & 3.007 & 1.237 & 1.529 & 5 \\
\hline $\begin{array}{l}\text { - Some of us have children } \\
\text { out of rape who disturb } \\
\text { us while sleeping so we } \\
\text { don't have good rest }\end{array}$ & 168 & 2.946 & 1.514 & 1.291 & 6 \\
\hline $\begin{array}{l}\text { When the weather is hot, } \\
\text { we have problem with } \\
\text { protection }\end{array}$ & 168 & 2.565 & 1.381 & 1.908 & 7 \\
\hline
\end{tabular}

Source (Field Data, 2022).

is the statement that "when it rains, those of us who sleep in front of shops are rendered "homeless". Certainly, sleeping in the open renders one susceptible to the vagaries of the weather. The fourth ranking is the response that "because some of us sleep in front of shops, we have to wake up as early as 4 am and this often affects our health". Brisk business in Accra business center start as early as $5 \mathrm{am}$ where big lorries and trucks begin to discharge consignment of goods. Some of the head porter girls partake of the off loading of goods and for this reason there is the need for them to wake up much earlier to prepare for the days work. Moreover, some shop owners get into their trading grounds as early as $5 \mathrm{am}$ and for that matter these girls must wake up earlier to enhance processes that will lead to the commencement of the days activities. The fifth response in ranking is the statement that "when we have stomach upset in the night, it is dif- 
ficult to find a comfortable place of convenience in good time". Added to this problem is the fact that most commercial places of convenience in the market areas close up operations as trading activities also windup in the evening. This means, the migrated girls in such areas are unlikely to enjoy the services of commercial toilet in the night. Ranking sixth with mean score of 2.946, standard deviation of 1.514 and variance of 1.291 was the statement that "some of us have children out of rape who disturb us while sleeping so we don't have good rest". Coming seventh in ranking is the response that "when the weather is hot, we have problem with protection".

\subsection{Objective Two on Employment Opportunities for Migrated Teenage Girls in Ghana}

Displayed hereunder are the results on the objective of examining the employment opportunities available to migrated teenage girls in Ghana while at Accra.

\subsubsection{The Kind of Jobs Available for Migrated Teenage Girls}

Shown in Table 6 are the findings on the kind of jobs migrated teenage girls and friends do in Accra.

Table 6 reflects the findings on the kind of menial jobs teenage girls and friends do in Accra. Ranking first with mean score of 3.890, standard deviation of 1.023 and variance of 1.046 was the statement that "head porter business at market centers". This is the main work available to migrated girls from the

Table 6. Frequency table on the kind of work teenage girls do in Accra.

\begin{tabular}{lccccc}
\hline \multicolumn{1}{c}{ Statement } & N & Mean & $\begin{array}{c}\text { Std. } \\
\text { Dev. }\end{array}$ & Variance & Rank \\
\hline $\begin{array}{l}\text { Head Porter business at } \\
\text { market centers }\end{array}$ & 168 & 3.890 & 1.023 & 1.046 & 1 \\
$\begin{array}{l}\text { Sales girl i.e. arranging } \\
\text { commodities for sale }\end{array}$ & 168 & 3.783 & 1.114 & 1.242 & 2 \\
$\begin{array}{l}\text { Sell sachet water at traffic } \\
\text { intersections }\end{array}$ & 168 & 3.782 & 0.943 & 0.889 & 3 \\
$\begin{array}{l}\text { Labourers in the chop bar } \\
\text { or food joints }\end{array}$ & 168 & 3.565 & 0.984 & 0.967 & 4 \\
$\begin{array}{l}\text { Domestic servants in some } \\
\text { homes }\end{array}$ & 168 & 3.285 & 1.127 & 1.271 & 5 \\
$\begin{array}{l}\text { Cleaners and janitors at } \\
\text { some offices }\end{array}$ & 168 & 3.003 & 1.085 & 1.176 & 6 \\
$\begin{array}{l}\text { Hawk cheap "reduce to } \\
\text { clear" items on the market }\end{array}$ & 168 & 2.947 & 1.162 & 1.350 & 7 \\
$\begin{array}{l}\text { Babysitters or nannies } \\
\text { - }\end{array}$ & 168 & 2.854 & 0.977 & 1.239 & 8 \\
\hline
\end{tabular}

Source (Field Data, 2022). 
North. They are known as Kayayei because they carry goods on their heads for people who have come to purchase commodities on the market for either resale or domestic use. The second ranking was the response that most of the girls are recruited as "sales girl i.e. arranging commodities for sale". At the end of the day, shops at the commercial center repack goods displayed outside into their shops. In the morning, such goods must be returned to the outside to as it were, promote visibility and encourage patronage. The store girls are responsible for this exercise. Coming third in ranking was the idea that to survive in Accra they "sell sachet water at traffic intersections". Selling at the road traffic intersection continues to be a lucrative business conducted by even girls in the South who have completed various vocations in hairdressing, dressmaking etc. but have no means of establishing themselves. The Northern girls therefore come in to make this street selling trade very competitive. The fourth response in ranking was the notion that these girls are also engaged as "labourers in the chop bar and food joints". Food joints require hands who will assist pound fufu physically, wash utensils, sweeping eating booths, run errands and serve as waiters and waitress. Most of these girls are said to be very smart in such responsibilities and are therefore preferred to their Southern counterparts when it comes to employment decisions. Ranking fifth is the response that some of these girls are engaged as "domestic servants in some homes". In Ghana, the affluent needs girls who would sweep their compound and perform other jobs to keep their surroundings clean. Most of these migrated girls do well in these areas too. Coming sixth in ranking was the statement that some of the migrated girls are also employed as "cleaners and janitors at some offices". Another kind of job teenage girls do in Accra is to "hawk cheap 'reduce to clear' items on the market" which came seventh in ranking. The eight ranking was the response that a good number of the migrated girls are also recruited as "babysitters or nannies" in some homes in Accra.

\subsubsection{Business Income and Living Conditions of Teenage Girls in Accra}

Featured in Table 7 are the findings on how their business incomes sustain their livelihood in the Accra business metropolis.

Gathered in Table 7 are the findings on how business incomes of the teenage girls sustain their livelihoods as well as meet their aspirations in life. Coming first in ranking is the response that through my business income "am able to feed two times in a day and save the rest of the income I receive". The second in ranking is the statement that from my business income "I feed myself and send money to my parent in the North". Most of these girls are motivated towards joining the internal migration because of precarious living conditions of their families in the North. It is therefore not surprising that after feeding themselves out of their business income, they remit their parents regularly.

Coming third in ranking is the response that through the business income " $\mathrm{I}$ feed myself and child out of proceeds from my work". Obviously, as the teenage girls grow in the business, they get into relationship and will logically have 
Table 7. Frequency table on business incomes and livelihood.

\begin{tabular}{|c|c|c|c|c|c|}
\hline Statement & $\mathbf{N}$ & Mean & $\begin{array}{l}\text { Std. } \\
\text { Dev. }\end{array}$ & Variance & Rank \\
\hline $\begin{array}{l}\text { Am able to feed two times in } \\
\text { a day and save out of the } \\
\text { income I receive }\end{array}$ & 168 & 4.074 & 0.597 & 0.356 & 1 \\
\hline $\begin{array}{l}\text { - I feed myself and send money } \\
\text { to my parent in the North }\end{array}$ & 168 & 3.890 & 1.023 & 1.046 & 2 \\
\hline $\begin{array}{l}\text { - I feed myself and child out of } \\
\text { proceeds from my work }\end{array}$ & 168 & 3.862 & 0.838 & 0.702 & 3 \\
\hline $\begin{array}{l}\text { From the proceeds of my } \\
\text { employment I have been } \\
\text { able to acquire basic tools } \\
\text { to start my trade }\end{array}$ & 168 & 3.640 & 0.977 & 0.955 & 4 \\
\hline $\begin{array}{l}\text { Out of my income I send } \\
\text { money home regularly for } \\
\text { the upkeep of parents } \\
\text { and siblings }\end{array}$ & 168 & 3.610 & 1.037 & 1.075 & 5 \\
\hline $\begin{array}{l}\text { Through my income am able } \\
\text { to go to hospital, after } \\
\text { acquiring NHIS }\end{array}$ & 168 & 3.570 & 1.185 & 1.404 & 6 \\
\hline
\end{tabular}

Source (Field Data, 2022).

children who must be fed through their business incomes. Coming fourth in Table 7 is the notion that "from the proceeds of my employment I have been able to acquire basic tools to start my trade". One of the identified factors for coming down to Accra had to do with the need to secure funds to establish vocations like hairdressing, dressmaking etc. which all require basic tools. The findings that some of their business incomes were applied in purchasing some of the equipment for their trade in up country is certainly a step in the right direction. Ranking fifth with mean score of 3.610, standard deviation of 1.037 and variance of 1.075 is the statement that "out of my income I send money home regularly to enable my parents pay the fees of my siblings". This finding is also not surprising since poor economic circumstances at home in the North pressurize some of these girls to migrate to Accra. Table 7 also reveals that "through income am able to go to hospital after acquiring NHIS". As a poverty reduction intervention, government of Ghana established the National Health Insurance Scheme (NHIS) under which the lower income group could access quality healthcare at highly subsidized rate. One has to register at a minimal fee to access services and through their business income they have been able to enlist with the scheme which will protect them and their children in the event of ill-health. 


\subsubsection{Employers Relationship with Teenage Girls in Accra}

Featured in Table 8 are the findings on the relationship between migrated teenage girls and their Accra employers.

Table 8 reflects the findings on employers' relationship with teenage girls. Ranking first with mean score of 3.500, standard deviation of 0.988 and variance of 0.976 is the response that "they give us the agreed wages regularly". It is heartwarming to learn that the business owners do not renege on their promises but pay negotiated wages to the teenage girls. The second ranking goes to the response that as "sales budget increases, they give us bonuses". It is equally heartwarming to learn that business owners in Accra pay bonuses to the teenage girls as and when budgeted sales are exceeded. This will certainly encourage the girls to use all tactics in convincing potential buyers to purchase their products thereby increasing revenue to the business owners. Table 8 also depicts the fact that "sometimes our masters try to abuse us sexually while serving as house helps". Amorous tendencies in such relationships are widespread and sometimes degenerate into legal tussles. Some male bosses also influence these girls with monies as way of covering up such sexual abuses. The sexual issue concerning male business owners was third in ranking. The fourth in ranking is another case of sexual assault but this time emanating from "the sons of our employers also abuse us sexually". Ranking fifth has to do with some health hazards associated in business relationship which involve the fact that "some of us who hawk on the street sometimes sustain motor accidents". The local newspapers in the past had

Table 8. Frequency table on the relationship between employers and teenage girls.

\begin{tabular}{|c|c|c|c|c|c|}
\hline Statement & $\mathbf{N}$ & Mean & $\begin{array}{l}\text { Std. } \\
\text { Dev. }\end{array}$ & Variance & Rank \\
\hline $\begin{array}{l}\text { - They give us the agreed wages } \\
\text { regularly }\end{array}$ & 168 & 3.500 & 0.988 & 0.976 & 1 \\
\hline $\begin{array}{l}\text { As budgeted sales increase, } \\
\text { they give us bonuses }\end{array}$ & 168 & 3.430 & 0.909 & 0.826 & 2 \\
\hline $\begin{array}{l}\text { - Sometimes our masters try to } \\
\text { abuse us sexually while } \\
\text { serving as domestic assistants }\end{array}$ & 168 & 3.393 & 1.195 & 1.428 & 3 \\
\hline $\begin{array}{l}\text { The sons of our employers } \\
\text { also abuse us sexually }\end{array}$ & 168 & 3.360 & 1.453 & 2.112 & 4 \\
\hline $\begin{array}{l}\text { Some of us who hawk on } \\
\text { the street sometimes sustain } \\
\text { motor accidents }\end{array}$ & 168 & 3.299 & 1.036 & 1.074 & 5 \\
\hline $\begin{array}{l}\text { - Sometimes when going back } \\
\text { home, they give us more } \\
\text { money for transport and } \\
\text { convenience }\end{array}$ & 168 & 3.280 & 1.127 & 0.982 & 6 \\
\hline
\end{tabular}

Source (Field Data, 2022). 
featured gory scenes of teenage girls selling on the street who have either been maimed or murdered through road accidents as a result of crossing vehicles in attempts to sell one or two items to moving vehicles. The situation is very dangerous yet not much has been done to deter these girls from embarking upon such life threatening moves. The seventh ranking in respect of relationship with employers also touches on the extra benefits the employers shower on the migrated girls in that "sometimes when going back home, they give us more money for transport and convenience".

\subsection{Objective Three on Challenges with Efforts at Curbing the North to South Migration}

Displayed under this segment are findings in respect to the objective of identifying challenges facing stakeholders' effort at curbing the North to south migration of teenage girls in Ghana.

\subsubsection{Government Agency's Constrains at Curbing North to South Migration in Ghana}

Featured in Table 9 are the findings on the challenges bedeviling efforts by the Ministry of Children and Women Affairs towards curbing the frequent migration of teenage girls from the North to the South.

Table 9 presents finding in respect of difficulties government agencies like Ministry of children and women affairs face in curbing the migration situation. Ranking first with mean score of 4.112, standard deviation of 0.597 and variance of 0.356 is the notion that "government plans at making them undergo apprenticeship is often thwarted because the girls want money quick". The second in ranking in terms of challenges is the idea that "government through Ministry of Children and Women Affair is organizing classes for some to go back to school but the girls are not interested". Coming third in ranking is the response "that some of the girls have the objective of making money in the south and going back to the north and so are not interested in government interventions". Ranking fourth is the fact that "the girls are usually scattered within the Accra metropolis and therefore its difficult tracing them for help". The fifth ranking is the response that "government efforts of making them undergo apprenticeship in various trades have not been successful because girls want quick money". The sixth response in ranking is that "government promises to build them hostels etc. have not materialized because of unavailability of funds" for the purpose.

\subsubsection{Role of Parents in Teenage Girls' Migration Efforts}

Depicted in Table 10 are the findings on the role of parents in promoting the migration of their teenage girls to Accra.

Table 10 shows findings on the role of parents in inadvertently promoting internal migration of their daughters from North to South. The first ranking is the statement that the "children send money back home to sustain the family". Parents see the teenage girls as an avenue for raising funds to buttress the financial base of the family and for that matter remain adamant to efforts at migrating the 
Table 9. Frequency table on the constraints facing Ministry of Children and Women Affair in combating teenage migration.

\begin{tabular}{|c|c|c|c|c|c|}
\hline Statement & $\mathbf{N}$ & Mean & $\begin{array}{l}\text { Std. } \\
\text { Dev. }\end{array}$ & Variance & Rank \\
\hline $\begin{array}{l}\text { - Government plans at making } \\
\text { them undergo apprenticeship } \\
\text { is often thwarted because the } \\
\text { girls want money quick }\end{array}$ & 168 & 4.112 & 0.597 & 0.356 & 1 \\
\hline $\begin{array}{l}\text { - Government through } \\
\text { Ministry of Children and } \\
\text { Women Affair is organizing } \\
\text { classes for some to go back to } \\
\text { school but the girls are not } \\
\text { interested }\end{array}$ & 168 & 3.963 & 1.037 & 1.075 & 2 \\
\hline $\begin{array}{l}\text { Some have the objective of } \\
\text { making money in the south } \\
\text { and going back to the north } \\
\text { and so are not having any } \\
\text { interest in government } \\
\text { interventions }\end{array}$ & 168 & 3.816 & 1.023 & 1.046 & 3 \\
\hline $\begin{array}{l}\text { The girls are usually scattered } \\
\text { within the Accra metropolis } \\
\text { and therefore its difficult } \\
\text { tracing them for help }\end{array}$ & 168 & 3.765 & 0.838 & 0.702 & 4 \\
\hline $\begin{array}{l}\text { - Government effort of making } \\
\text { them undergo apprenticeship } \\
\text { in various trades have not } \\
\text { been successful because girls } \\
\text { want quick money }\end{array}$ & 168 & 3.510 & 1.185 & 1.404 & 5 \\
\hline $\begin{array}{l}\text { - Governments' promises to } \\
\text { build them hostels etc. have } \\
\text { not materialized because of } \\
\text { unavailability of funds }\end{array}$ & 168 & 3.316 & 0.977 & 0.955 & 6 \\
\hline
\end{tabular}

Source (Field Data, 2022).

girls to the South. Coming second in ranking is the finding that "parents continue to give their teenage girls into marriage who therefore run away from being third and fourth wives". This is another key reason why the girls dessert the North. In an attempt to raise income to fend for themselves, parents push their daughter into becoming third and fourth wives to seemingly rich cattle owners in the North. Most of these men are much older and these girls leading to the situation where they run away from such forced marriages. The statement that "because of poverty, parents are unable to properly keep their children in basic school although fees are free" came third. Basic schools as well as tertiary education in Ghana is completely free, however, some parents in the North are so poor 
Table 10. Frequency table on parents role in girls migration activities.

\begin{tabular}{lccccc}
\multicolumn{1}{c}{ Statement } & N & Mean & $\begin{array}{c}\text { Std. } \\
\text { Dev. }\end{array}$ & Variance & Rank \\
\hline $\begin{array}{l}\text { The children send money } \\
\text { back home to sustain the } \\
\text { family }\end{array}$ & 168 & 3.876 & 0.777 & 0.558 & 1 \\
$\begin{array}{l}\text { Parents continue to give } \\
\text { their teenage girls into } \\
\text { marriage who therefore } \\
\text { run away from being third } \\
\text { and fourth wives }\end{array}$ & 168 & 3.790 & 1.019 & 1.038 & 2 \\
$\begin{array}{l}\text { Because of poverty, parents } \\
\text { are unable to properly keep } \\
\text { their children in basic } \\
\text { school although fees are } \\
\text { free }\end{array}$ & 168 & 3.710 & 0.886 & 0.785 & 3 \\
$\begin{array}{l}\text { Parents have too many } \\
\text { children to look after and } \\
\text { therefore deem it } \\
\text { appropriate to send some } \\
\text { away to work for revenue } \\
\text { for family's upkeep }\end{array}$ & & & & & \\
\hline
\end{tabular}

Source (Field Data, 2022).

that offering breakfast and means of transport for the girls to go to school become a headache thereby making the girls truant as far as school attendance is concerned. Running away to the South is therefore seen by the girls as a golden opportunity to better their living systems in the future.

The fourth ranking with mean score of 3.670, standard deviation of 1.029 and variance of 1.059 goes to the statement that "parents have too many children to look after and therefore deem it appropriate to send some away to work for revenue".

\subsection{Objective Four on Strategies for Discouraging North to South Migration of Teenage Girls in Ghana}

Featured herein are the findings to the objective of exploring strategies for discouraging North to south migration of teenage girls in Ghana.

\subsubsection{Efforts to Stamp out Migration of Teenage Girls in Ghana}

Shown in Table 11 are the findings in respect to the efforts being made to stamp out the menace of teenage girls migrating from the North to South

Table 11 presents various strategies for stamping out teenage girl migration from the North to the South of Ghana. Ranking first with mean score of 3.570, standard deviation of 1.185 and variance of 1.404 is the statement that "free basic 
Table 11. Frequency table on the strategies to curb the migration of teenage girls.

\begin{tabular}{|c|c|c|c|c|c|}
\hline Statement & $\mathbf{N}$ & Mean & $\begin{array}{l}\text { Std. } \\
\text { Dev. }\end{array}$ & Variance & Rank \\
\hline $\begin{array}{l}\text { Free basic school should be } \\
\text { intensified to include } \\
\text { clothing, textbook, and } \\
\text { footwear }\end{array}$ & 168 & 3.570 & 1.185 & 1.404 & 1 \\
\hline $\begin{array}{l}\text { Free feeding of schools in the } \\
\text { public sector must be for } \\
\text { both breakfast and lunch }\end{array}$ & 168 & 3.530 & 0.988 & 0.976 & 2 \\
\hline $\begin{array}{l}\text { - Civil society organizations } \\
\text { must conscientize parents on } \\
\text { the need to keep their } \\
\text { children in school }\end{array}$ & 168 & 3.430 & 0.909 & 0.826 & 3 \\
\hline $\begin{array}{l}\text { - Churches and mosques at } \\
\text { the north must appeal to } \\
\text { parent not to force their } \\
\text { children to becoming } \\
\text { additional wives to old men }\end{array}$ & 168 & 3.399 & 1.195 & 1.428 & 4 \\
\hline $\begin{array}{l}\text { - The concept of sending girl } \\
\text { child to school must be } \\
\text { revisited through a strong } \\
\text { campaign in the north }\end{array}$ & 168 & 3.360 & 1.453 & 2.112 & 5 \\
\hline $\begin{array}{l}\text { - Government should help } \\
\text { cottage industries in the } \\
\text { North with funds, } \\
\text { infrastructure such as } \\
\text { irrigation systems to } \\
\text { improve living in } \\
\text { the North }\end{array}$ & 168 & 3.294 & 1.036 & 1.074 & 6 \\
\hline
\end{tabular}

Source (Field Data, 2022).

school should be intensified to include clothing, textbook, and footwear". The second ranking is the idea that "free feeding of schools in the public sector must be for both breakfast and lunch". The statement that "civil society organizations must conscientize parents on the need to keep their children in school" came third in ranking. Coming fourth in ranking is the idea that "churches and mosques at the north must appeal to parent not to force their children to becoming additional wives to old men". The fifth suggestion in ranking is that "the concept of sending girl child to school must be revisited through a strong campaign in the north". The sixth ranking is the statement that "government should help promote cottage industries in the North with funds, infrastructure such as irrigation systems to improve living in the North". 


\subsubsection{Gender Ministry's Arrangements for Addressing Teenage Girls Migration Issue}

Featured in Table 12 are the findings in respect to the arrangements being made by the Ministry of Children and Women Affairs to address the problem of teenage girls' internal migration in Ghana.

Table 12 depicts findings on Ministry of Children and Women Affairs Arrangements to Address Teenage Girls Migration Problem. Coming first in ranking is the idea that "strengthening education systems in the north with free school fees, book supply, feeding both breakfast and lunch, footwear etc. will keep the children in school and can help curb the menace of migration among the teenage girls". The second ranking with mean score of 3.550, standard deviation of 0.985 and variance of 0.971 goes to the statement that "a lot more vocational institutions must be established to inculcate vocational trade in the communities". The third suggestion in ranking is that "upon completion of apprenticeship, funds must be available for the girls to establish their own businesses". Ranking fourth is the idea that "government advocacy programmes must be sent

Table 12. Frequency table on arrangements towards addressing teenage girl migration problems in Ghana.

\begin{tabular}{|c|c|c|c|c|c|}
\hline Statement & $\mathbf{N}$ & Mean & $\begin{array}{l}\text { Std. } \\
\text { Dev. }\end{array}$ & Variance & Rank \\
\hline $\begin{array}{l}\text { - Strengthening education } \\
\text { systems in the north with } \\
\text { free school feeds, book } \\
\text { supply, feeding, footwear } \\
\text { etc. to keep the children in } \\
\text { school }\end{array}$ & 168 & 3.560 & 1.294 & 1.673 & 1 \\
\hline $\begin{array}{l}\text { A lot more vocational } \\
\text { institutions must be } \\
\text { established to inculcate } \\
\text { vocational trade in the } \\
\text { communities }\end{array}$ & 168 & 3.550 & 0.985 & 0.971 & 2 \\
\hline $\begin{array}{l}\text { - Upon completion of } \\
\text { apprenticeship, funds must } \\
\text { be available for the girls to } \\
\text { establish their own } \\
\text { businesses }\end{array}$ & 168 & 3.220 & 1.003 & 1.007 & 3 \\
\hline $\begin{array}{l}\text { Government advocacy } \\
\text { programmes must be sent } \\
\text { to schools, churches, } \\
\text { mosques for parent and } \\
\text { girls to appreciate the need } \\
\text { for girls to remain in } \\
\text { schools }\end{array}$ & 168 & 2.708 & 1.145 & 1.235 & 4 \\
\hline
\end{tabular}

Source (Field Data, 2022). 
to schools, churches, mosques for parent and girls to appreciate the need to remain in schools".

\subsubsection{Addressing Current Problems with Migrated Girls in Accra}

Presented hereunder are the findings in respect to how challenges facing migrated girls in Accra can be ameliorated.

Table 13 shows findings on how government should address the existing challenges facing migrated girls in Accra. The first ranking with mean score of 3.930, standard deviation of 0.708 and variance of 0.501 is the suggestion that "government must fulfil its promise for constructing hostels for teenage girls in

Table 13. Frequency table on ways for addressing problems teenage migrated girls in Accra are currently facing.

\begin{tabular}{|c|c|c|c|c|c|}
\hline Statement & $\mathbf{N}$ & Mean & $\begin{array}{l}\text { Std. } \\
\text { Dev. }\end{array}$ & Variance & Rank \\
\hline $\begin{array}{l}\text { Government must fulfil its } \\
\text { promise for constructing } \\
\text { hostels for teenage girls in } \\
\text { Accra so as to give them } \\
\text { decent places to sleep }\end{array}$ & 168 & 3.930 & 0.708 & 0.501 & 1 \\
\hline $\begin{array}{l}\text { - Government must enroll the } \\
\text { girls in vocational institutions } \\
\text { where they are freely fed and } \\
\text { given pocket money to cater } \\
\text { for their basic needs }\end{array}$ & 168 & 3.892 & 1.121 & 1.256 & 2 \\
\hline $\begin{array}{l}\text { Government must help those } \\
\text { who want to re-enter formal } \\
\text { sector education to do so } \\
\text { under comfortable } \\
\text { arrangements }\end{array}$ & 168 & 3.860 & 0.838 & 0.702 & 3 \\
\hline $\begin{array}{l}\text { - Government must strengthen } \\
\text { the Livelihood Empowerment } \\
\text { Against Poverty (LEAP) } \\
\text { stipends to reach destitute } \\
\text { parents in the north so as to } \\
\text { prevent their daughters from } \\
\text { coming down to do menial } \\
\text { jobs to support their family }\end{array}$ & 168 & 2.843 & 1.065 & 1.135 & 4 \\
\hline $\begin{array}{l}\text { From time to time, ladies } \\
\text { from the north who are } \\
\text { working in reputable } \\
\text { organizations must visit these } \\
\text { girls to counsel them on the } \\
\text { need to be in school in order } \\
\text { to become like them }\end{array}$ & 168 & 2.590 & 0.865 & 0.749 & 5 \\
\hline
\end{tabular}

Source (Field Data, 2022). 
Accra so as to give them decent places to sleep". Coming second in ranking is the suggestion that "government must enroll the girls in vocational institutions where they are freely fed and given pocket money to cater for their basic needs". The idea that "government must help those who want to re-enter formal sector education to do so under comfortable arrangement" came third. The fourth suggestion in ranking is that "government must strengthen the Livelihood Empowerment Against Poverty (LEAP) stipends to reach destitute parents in the north so as to prevent their daughters from coming down to do menial jobs". Ranking fifth is the statement that "from time to time, ladies from the north who are working in reputable organizations, under a mentorship programme must visit these girls to counsel them on the need to remain in school in order to become like them".

\section{Discussion of Findings}

This segment of the article discusses the findings of the study and these have been conducted in consonance with the study objectives. Objective one identified the factors which promote North to South internal migration of Ghanaian teenage girls. Findings include the fact that they were being forced into child marriage by selfish parents as second, third or even fourth wives of seemingly well to do cattle owners or farmers in their hometown. This finding was corroborated by Kwankye (2012) in a similar study in which he pointed out that some poor parents default in repayment of loans solicited from richer folks in the villages and therefore offer their teenage girls as wives to retire such loans burdens hanging on their necks. Most of these girls according to UNFPA (2012) are often not comfortable with the matrimonial arrangement and sometimes migrate to the South or elope with their chosen boyfriends. Although child marriage has been outlawed in Ghana making it punishable for any parent to accept dowry for their daughter below 18 year, the practice still persist in the five Northern regions of the country (Hansard, 2014). The latter explains that it is from this background that most parents in the Northern regions of Ghana are not keen on sending on investing education and training of their daughters. The mentality is that eventually the girls will become wives and serve men and will no longer be useful to the parent. Government efforts at discouraging this practice through free education for basic and secondary schools according to Andoh (2021) have gone a very long way to minimize the practice in the towns and sub-urban areas of the Northern regions although the practice still persist in the hinterlands. On the international front, Ojuolape (2021) noted that in consonance with the global program of United Nations Population Fund (UNFPA) i.e. "leaving no one behind", the organization is partnering the Chief Justice Mentorship program in Ghana to provide opportunities for head porter girls (Kayayei) to build their self-image as well as provide the needed support for developing their various life path careers.

The study also found out that, these teenage girls run away from the North to 
the South because after learning trade, they receive no support for establishing themselves towards irking a respectable business life. This has also been mentioned in a study by Yeboah (2010) who recounted among the factors that trigger North to South internal migration in Ghana as inadequate opportunities for assisting the young entrepreneurs to establish small scale businesses as means of livelihood. The source continued that these girls often become disillusioned and the only option exercisable is to join the North to South migration train. In this regard, Kwankye et al. (2007) recommended that adequate infrastructure and social amenities should be established country wide to enable the youth use their hands in irking a living rather than migrating to the South from the North or leaving the country for seemingly greener pastures. In another study, Kwankye et al. (2009) also appealed to the numerous NGOs operating in the three Northern regions of Ghana especially the world class groups like the British DFID or OXFAM, Danish DANIDA, Japanese JICA, American TECNOSERVE, German GIZ etc. to assist the government to improve upon the structures for creating jobs in these seemingly deprived communities of the country. This way, the source notes that the youth especially teenage girls will find something lucrative doing and will not be motivated to migrate South wards for menial jobs. It came out unequivocally that another factor which sustains the North to South internal migration in Ghana has to do with pressure bestowed on the girls back home as a result of sighting the seemingly improved living conditions of the returnees. Studies by Awumbila and Ardayfio-Schandorf (2008) also revealed that the sudden change in lifestyle of friends and family members who return from the South as evidenced by their clothing, footwear, necklace etc. is so captivating that the other girls have no option but to prepare themselves to also migrate South wards. This, Afriyie et al. (2015) attribute to the rationality nature of human beings and also calls for improvement in job creating avenues in the North so as to enable these girls and the youth find jobs in their geographical areas where adequate income can be received to also improve their lifestyles. The source continues that when job seeking opportunities are evenly distributed, commercial activities will certainly spring up in the deprived areas as well and one needs not come down South to work and acquire necessities of life because all these will also be available in the North. The study further revealed that most families in the Northern region has too many children and given their limited resources it is difficult taking adequate care of the young ones and this also forces the hungry young ones to migrate to the South. Writing on the living conditions of female head porter girls (Kayayei) in the second city of Ghana i.e. Kumasi, Baah-Ennumh et al. (2012) lamented over the fact that hunger and high levels of deprivations drove some of these teenage girls from the North to the South and blamed population management authorities for poor advocacy programs which did not go well enough to raise awareness for the need to have reasonable size families. The source further appealed to the health authorities through the community health department to intensify family planning cam- 
paigns and impress upon the citizenry especially those in the deprived communities to employ available safe and almost free birth control mechanisms for improving upon their socio-economic circumstances. This way they would have number of children they can adequately cater for thereby reducing the tendency for these hungry children to migrate to the South to fend for themselves. The study also wanted to examine the mechanisms for leaving the North to the South by the teenage girls and it was revealed that some girls collect money from friends for the transportation to Accra, while others steal money from parent or family members to come to Accra. Others too are remitted from friends in Accra through the telephone mobile money system to facilitate their journeys down to Accra. Some of these revelations have been made by Kwankye (2012) in his article calling on government and other stakeholders to support investments in the Northern regions of Ghana. The source notes that the practice continues because friends and family members easily release funds for their compatriots to migrate South wards for greener pastures. The study found out that the young girls married as third or fourth wives often find money through illegal means from their husbands and run away to the South to seek freedom and better living conditions. Some girls receive travelling funds from their boyfriends while some parents support the migration of their children because they see no future for them in the North. The Government of Ghana's parliamentary Hansard (2014) records proceedings on debate aimed at creating better living conditions in the North through connecting every community to the national electricity grid, improving infrastructure especially roads to attract factories, modernizing hospitals towards making quality healthcare available to the deprived communities in the North. It is believed that when all these strategies come on board, economic opportunities in this region will bubble for brisk businesses to precipitate. This will lead to more job avenues being created thereby discouraging the rampant North to South migration in search of menial jobs for minimizing the misery associated with most of the families in the Northern regions of Ghana.

The second objective sought to evaluate the employment opportunities available to migrated teenage girls in Accra. The study noted that these girls are mainly engaged as female head porters (Kayayei) in the market centers, while others are recruited as sales girls tasked with arranging commodities for sale. Some also sell sachet water at traffic intersections with others engaged as waiters and kitchen hands at food joints or "chop bars". Writing on female porters living conditions Baah-Ennumh et al. (2012) noted that jobs available for these girls primarily involve head porter business within the city center markets and shop girl positions, who are mainly errand attendants for the shop owners. Others the source noted leverage on their savings to do petty trading through hawking Giffen-goods and other commodities on the market. It also came to light that a good number of them who are able to learn quickly the Akan, Ga dialect i.e. languages usually spoken in Accra, are able to secure somewhat more dignified jobs as domestic labourers and nannies. Others too manage to enter the em- 
ployment of some offices as cleaners or janitors while others graduate from the Kayayei business and embark upon hawking in cheap "reduced to clear" items on the market. Yeboah and Appiah-Yeboah (2009) also discussed the socio-cultural profile of the head porters and observed that those who are able to learn the Southern languages especially Twi and Ga often add value to their job seeking prospects and get engaged as domestic servants and nannies where they sleep at better places, eat good food and enjoy enhanced living systems relative to their colleagues who remain as head porters or shop assistants. On the issue of the extent to which their business income addresses their aspirations, it came out that the Kayayei are able to feed two times a day and save the rest of their daily incomes. Through the income received, these girls are able to feed themselves and remit their parents back in the North while others with children born in Accra also feed themselves and children from their daily wages. In his article on "The kayayei: Survival in the City of Accra" Van den-Berg (2007) notes that the female head porters manage to save out of their daily wages after feeding themselves, children as well as sending remittances to their parents and loved ones back home. The source continues that these girls have made it a policy and often discipline themselves to the extent that no matter the size of the daily wage they are able to reserve a fraction to augment their savings. Van den-berg (2007) noted that some Kayayei, out of the proceeds of their employment acquire basic tools to commence trade either in hairdressing, dressmaking and other cosmetology businesses especially manicure and pedicure. Through their daily incomes, they are able to acquire National Health Insurance Scheme (NHIS) membership and enjoy medicare when sick. The study further examined the relationship between the female head porters and their employers. It was revealed that the employers honour their promise by paying them the agreed wages regularly with some receiving bonuses when sales target are exceeded. Afriyie et al. (2015) mentioned in an article on survival of Kayayei in Accra that most of them received negotiated wages from their patrons and the girls seem to be happy with this arrangement. Unfortunately, those engaged as domestic workers and sleep in better rooms and enjoy better living infrastructure are sometimes abused sexually by their masters as well as their grown up sons. The source continue that some become pregnant and deliver such children who sometimes add sorrow to their plight since the meager wages will now be extended to the up keep of the baby. Some of the challenges with the working conditions also involve sustaining motor accidents especially those who hawk sachet water and non-alcoholic beverages at traffic light intersections. On places where the Kayayei sleep in Accra, the study noted that majority sleep in front of shops where they work while others find sleeping dwellings among wooden structures at the road side. Others manage to sleep in windowless metal container shops near where they work while some pull their resources together and six of them rent single room dwellings in compound houses. These dwelling places have been corroborated by Afriyie et al. (2015) whose article "Socio-Economic Impli- 
cations for Young Female Head Porters" discussed extensively the precarious conditions under which most of these girls sleep in Accra. The source recommended to government agencies and other NGOs to endeavor to create transitional decent hostel accommodations for these girls who are suffering as a result of inequalities in the distribution of infrastructure, social amenities and other life enhancement systems. The study probed into the problems associated with their sleeping places and observed that unscrupulous drug addiction boys often raid their sleeping places with knives to forcibly take their daily wages and savings from them. Some of these attackers also rape them when they do not have money to offer them. Another disturbing issue has to do with the fact that whenever there is heavy down pour, these girls are rendered "homeless" and for that matter, sleeping becomes impossible thereby compromising on their health status and reducing their readiness to work happily the following day. Afriyie et al. (2015) also narrated some these harrowing experiences the ladies go through at night and wondered if some protection cannot be established to ward off the attack of the activities of these miscreants. Afriyie and his colleagues also mentioned the fact that because some of these girls sleep in front of shops, they have to continually wake up as early as 4 am and this often affects their health status. Wilson and Mittelmark (2013) also lamented over the fact that no places of convenience exist for these ladies and for that matter when they have stomach upset at night they experience difficulties in making themselves comfortable. The source further mentioned the fact that some of these girls experience sleepless nights because the children they had from rape cases disturb them while sleeping leading to weakening their propensity towards working soundly the following morning. Van den-Berg (2007) also corroborated the finding that when the weather is hot, these girls have challenges with protection since they do not cover themselves and those wayward boys ransack their premises stealing their food, money and anything they could carry away.

The third objective attempted to identify challenges bedeviling stakeholders' effort at curbing the North to South migration of teenage girls in Ghana. Accordingly, the study wanted to appreciate efforts being made by the Gender Ministry and Children Affairs to reduce the practice. It came out unequivocally that government plans at making them learn trade through undergoing apprenticeship has often thwarted because the girls want quick money and are not ready to sacrifice for their own future gains. This issue has been well pronounced in an article on "Confronting the Challenges: Optimizing Child Rights in Ghana" by Apt, Agbenyiga and Ame (2011) who noted that deviant girls who were put in government training programmes at National Vocational Training Institute (NVTI) often absconded because they need ready money and usually establish themselves at traffic intersections selling chilled beverages, sachet water and some delicacies. These writers are of the view that some additional incentives can be put in place to motivate these girls to stay on training such weekly stipends, exciting entertainment program and the need to find them jobs after the 
training program. It also came out that government through Ministry of Children and women affair is organizing classes for some to go back to school but the girls are not interested and rather prefer hitting the roads to make money. This, in the view of Ojuolape (2021) is the reason why the UNFPA is collaborating with Ghana's Chief Justice Mentorship Program to ensure that no one is left behind in the global agenda towards building strong human capital for posterity. The source continues that the UNFPA is in collaboration with Civil Society Organizations (CSOs) toward ensuring that these less privileged girls and boys are motivated to stay in classroom or learn trade towards building a better future for themselves and the community as a whole. The government officials also recounted their difficulties in gathering the girls who are sparsely scattered within the Accra metropolis. This challenge according to Afriyie et al. (2015) can be surmounted if government agencies and NGOs collaborate with attractive packages to lower the girls into the classroom for formal education or learning trade. It also came out that adequate funding is disrupting government efforts at building decent sleeping places in the form of hostels to temporarily accommodate these girls while plying their Kayayei trade in the metropolis. This issue of funding challenges continues to be mentioned by a good number of writers on rehabilitating Kayayei and other underprivileged youth members. The Ghana's parliamentary Hansard (2014) impressed upon the government to endeavor to allocate funds for rehabilitating these girls especially their sleeping abodes so as to shield them from the vagaries of the weather as well as the activities of these dangerous boys who attack them at night to disposes them of their savings and sometimes rape them in the process.

\section{Conclusions and Recommendations}

\subsection{Conclusion}

Internal migration in Ghana involving teenage girls and other youth members from the five Northern region of Ghana to the South, has persisted for nearly three decades yet no serious attempt has been made to curb the practice which is adversely affecting the human capital stock of the country. The study therefore examined the challenges of curbing North to South migration of teenage girls in Ghana so as to prescribe appropriate recommendations. Factors identified for promoting North to South migration of teenage girls include under-aged girls running away from forced marriages, the need to travel South to gather funds to establish trade back home and the intention of parents to curtail girls education in favour of marrying them out as a second and third wives to satisfy parents' parochial interest. Other factors sustaining the North to South internal migration in Ghana impinge on peer pressure from returnee seemingly rich colleagues, poor social amenities and infrastructure in the North relative to the South, absence of electric light in some areas of the North and poor living conditions as a result of large family sizes.

Migrated teenage girls usually fit into available menial job openings such as 
female head porters at the market centers, sales girls for arranging commodities for sale and run errands for their employers as well as selling chilled sachet water and other bottle beverages at road traffic intersections. Other jobs available for these girls include assistants at food joints popularly called chop bars, domestic servants or nannies with a few of them being engaged as cleaners and janitors in some corporate office environments.

Challenges bedeviling stakeholders' efforts at curbing the North to South internal migration in Ghana include lack of interest by migrated girls in undergoing apprenticeship for vocational training or get back to formal classroom work owing to their desire to make quick money to meet exigencies. Most of the girls are scattered across the metropolis and for that matter it is difficult gathering them for schooling and skills development purposes. Government also faces the challenge of amassing funds to build decent transit hostels for these girls. Most of the girls are the breadwinners who send monthly stipends for the upkeep of their families back home and therefore are not interested in any classroom work. Although national laws debar parents from marrying out their daughters under 18 years, the practice persists in the North where the girls are forced into marriages leading to their decision to run away to the South and in the process sustain the drift of teenage girls from the three Northern regions. Poor infrastructural and social amenities framework in the three Northern regions also force the youth especially the teenage girls to migrate to the South to enjoy modern systems of living.

Generally, the study notes that the drift of teenage girls from the North to the South for menial jobs will be difficult to curb as far as promoting factors enumerated above continue to propagate unabated. Government and friendly Civil Society Organizations (CSOs) must collaborate and cooperate towards making life in the Northern regions more palatable. Laws on under-aged marriages must also be strictly enforced with a few defaulting parents punished to serve as deterrent to like-minded parents.

\subsection{Recommendations}

In the light of the challenges uncovered in the study, the following recommendations are worth considering by stakeholders especially government of Ghana and leading CSOs.

\subsubsection{Education, Training and Skill Development for Migrated Girls}

The study noted that some of the migrated teenage girls dropped out of basic schools and vocational training facilities while others too have completed learning trade but came down to look for funds to establish their vocational trade back home. It is from this background that the study recommends to the Government of Ghana and stakeholders to endeavor to get these girls back to the classroom and vocational schools in the metropolis. To start with, government should build befitting hostel facilities where these girls can be kept en-bloc in various locations in the metropolis where they will be fed, clothed and provide 
means of transport to various training grounds. Essentially, they should be exposed to weekly stipends necessary to keep their minds at bay towards creating the fertile grounds for them to assimilate training packages models or learning outcomes. Arrangements should be made for effective monitoring of these girls in order not to defray the purpose of the project.

\subsubsection{Improving Socio-Economic Conditions in the Three Northern Regions}

The study noted with regret that some of these teenage girls are forced to migrate downward to the South to make money to feed other siblings and parents back home. Certainly, this would not have happened if economic situations in the North had been buoyant enough for their parents to irk decent living. Accordingly, the study recommends that as a matter of urgency, government makes efforts to improve upon the infrastructure base of the Northern regions especially connecting all communities to the national grid, modernizing the road network in the regions to ensure that food items harvested on the farms especially tomatoes, yams, maize, shear nuts, beans and other cereals do not get rotten on the farms but are swiftly transported to the buying centers for these farmers to enjoy the fruit of their labour. Government should also consider deepening the implementation of the One Village One Dam (1V1D) policy to ensure that farmers do not depend upon rainfall towards determining the prospects of their farming activities. Incentives should be put in place to encourage investors to establish factories in these regions to process some of these primary produce like tomatoes, cattle, shear nut, beans etc. into secondary exportable products. This way more job openings will precipitate in the North for the citizenry to earn better wages towards improving their living standards.

\subsubsection{Intensification of Family Planning Awareness Campaign}

In Ghana, the Northern regions are predominantly inhabited by such ethnic groups as Gonjas, Mamprusis, Dagombas, Chekosis, Komkombas, Bimobas, Vaglas and Nanumbas who are mainly Muslims with polygamy being held in high esteem. Fertility rate is very high in these regions and owing to their low level of education, family planning awareness is relegated to the background. Men marry up to four wives and have numerous children whose up keep is often well beyond their limited resources. The study found out that youth members, especially teenage girls who experience hardships, living under very trying economic conditions often exercise the option of joining migration wave to the South for greener pastures. It is hereby recommended that the community health department of the Ministry of Health intensify efforts at re-launching family planning awareness campaign in the North emphasizing on the need to employ birth control facilities. This way, parents could streamline their family sizes and ensure that they give birth to only children they can conveniently cater for. To strengthen the advocacy program, government should consider subsidizing the tariffs on birth control materials with the possibility of distributing some like the female and male condoms free of charge. The community health nurses should 
be well equipped with motor bikes to visit villages and hamlets with the view to carrying the birth control "gospel" to all the corners of the Northern hemisphere of the country. This way, parents will be well briefed on the importance of family planning and have children they can adequately cater for, thereby preempting the need for pushing children Southwards in search of funds to support the family back home.

\section{Acknowledgements}

Coming up with this publication will have been extremely difficult without the contribution of some good people who worked behind the scenes. The leaders of the female market porter (Kayayei) groups in the various markets especially Furama Lamprusi (Makola Market), Merri Alhassan (Agbogboloshie Market), Abiba Haruna (Dansoman Market), Kadija Hammond (Kaneshie Market), Mamunatu Adams (Osu Market), Fati Lomoh (Mallam Market), Aisha Habibi (Abeka Market) and Mariama Yakubu (Anyaa Market), all deserve commendation for creating the fertile grounds for the research team to meet the girls to solicit information towards meeting the objectives of the study. The team's interpreters Alhassan Yakubu and Farida Abubakar also must be mentioned for the expert manner they handled the translation work. The study is also grateful to some officials of the Gender Women and Children Ministry who exposed us to some efforts being made by their outfit, on behalf of the government, to curb this internal migration trend. Special thanks further goes to the highway long distance drivers Kwaku Yawson and Alfred Mensah, of the OAA Transport Services who have been conveying some of these girls and passengers from the North to the South, for the useful information they volunteered in respect of the transport arrangements available to the migrants. God richly bless you all.

\section{Conflicts of Interest}

The author declares no conflicts of interest regarding the publication of this paper.

\section{References}

Afriyie, K., Abass, K., \& Boateng, M. (2015). A Journey to the South: Socio-Economic Implications for Young Female Head Porters in the Central Business District of Kumasi, Ghana. International Journal of Migration and Residential Mobility, 1, 176-194. https://doi.org/10.1504/IJMRM.2015.074176

Akinsanmi, O. A. (2005). Gender Relations and Food Security in Imo State, South East, Nigeria. In W. Doppler (Eds.), Farming and Rural Systems Economics (Vol. 68, p. 254). Margraf Verlag Weikersheim.

Alston, M. (2007). Globalisation, Rural Restructuring and Health Service Delivery in Australia: Policy Failure and the Role of Social Work? Health \& Social Care in the Community, 15, 195-202. https://doi.org/10.1111/j.1365-2524.2007.00696.x

Andoh, D. (2021). Living No One Behind: Chief Justice, UNFPA Mentor Kayayei. Daily Graphic, 21722, 13. http://www.graphic.com.gh 
Apt, N. A., Agbenyiga, D. L., \& Ame, R. K. (2011). Confronting the Challenges: Optimizing Child Rights in Ghana. In K. Robert, R. K. Ame, L. DeBrenna, D. L. Agbenyiga, \& N. A. Apt (Eds.), Children's Rights in Ghana: Reality or Rhetoric (pp. 1-13)? Mot Juste Limited.

Archambault, C. S., de Laat, J., \& Zulu, E. M. (2012). Urban Services and Child Migration to the Slums of Nairobi. World Development, 40, 1854-1869.

Awumbila, M., \& Ardayfio-Schandorf, E. (2008). Gendered Poverty, Migration and Livelihood Strategies of Female Porters in Accra, Ghana. Norsk Geografisk Tidsskrift, 62, 171-179. https://doi.org/10.1080/00291950802335772

Baah-Ennumh, T. Y., Amponsah, O., \& Owusu Adoma, M. (2012). The Living Conditions of Female Head Porters in the Kumasi Metropolis, Ghana. Journal of Social and Development Sciences, 3, 229-244. https://doi.org/10.22610/jsds.v3i7.707

Bhagat, R. B. (2005). Rural-Urban Classification and Municipal Governance in India. Singapore Journal of Tropical Geography, 26, 61-73. https://doi.org/10.1111/j.0129-7619.2005.00204.x

Bhagat, R. B., \& Jones, G. (2014). Demographic Dynamics of Mega-Urban Regions: The Case of Mumbai. Demography India, 43, 71-94.

Bhagat, R. B., \& Mohanty, S. (2009). Emerging Pattern of Urbanization and the Contribution of Migration in Urban Growth in India. Asian Population Studies, 5, 5-20. https://doi.org/10.1080/17441730902790024

Cai, F., Du, Y., \& Wang, D. (Eds.) (2011). Report on China's Population and Labor (No. 12). Social Sciences Academic Press (China).

Census of India (2017). SRS Based Life Table 2011-15. Office of the Registrar General and Census Commissioner.

http://www.censusindia.gov.in/Vital Statistics/SRS Life Table/Srslife Table 2011-15. $\underline{\mathrm{html}}$

Chan, K. W. (2007). Misconceptions and Complexities in the Study of China's Cities: Definitions, Statistics, and Implications. Eurasian Geography and Economics, 48, 382-412. https://doi.org/10.2747/1538-7216.48.4.383

Chan, K. W. (2009). The Chinese Hukou System at 50. Eurasian Geography and Economics, 50, 197-221.

Chan, K. W. (2010). China's City Population Statistics and Implications for Economic Analysis. In F. Cai, Y. Du, \& Z. Zhang (Eds.), Reports on China's Population and Labor No. 11: Labor Market Challenges in the Post-Crisis Era (pp. 236-247). Social Science Academic Press.

Coccia, M. (2009). A New Approach for Measuring and Analyzing Patterns of Regional Economic Growth: Empirical Analysis in Italy. Ital J Reg Sci Sci Reg, 8, 71-95.

Coccia, M. (2017). A Theory of General Causes of Violent Crime: Homicides, Income Inequality and Deficiencies of the Heat Hypothesis and of the Model of CLASH. Aggression and Violent Behavior, 37, 190-200.

Coccia, M. (2019). The Theory of Technological Parasitism for the Measurement of the Evolution of Technology and Technological Forecasting. Technological Forecasting and Social Change, 141, 289-304. https://doi.org/10.1016/j.techfore.2018.12.012 https://www.sciencedirect.com/science/journal/00401625

Cole, W. E., \& Sanders, R. D. (1985). Internal Migration and Urban Employment in the Third World. American Economic Review, 75, 481-494.

Collado, D., Cantillon, B., Van den Bosch, K., Goedemé, T., \& Vandelannoote, D. (2016). The End of Cheap Talk about Poverty Reduction: The Cost of Closing the Poverty Gap 
While Maintaining Work Incentives. ImPRovE Working Paper No. 16/08. Antwerp: Herman Deleeck Centre for Social Policy, University of Antwerp.

Duke, C., Osborne, M., \& Wilson, B. (2013). A New Imperative: Regions and Higher Education in Difficult Times. Manchester University Press.

Edgar, C., Sarah, H., \& Andy, M. (2016). The Ghana Poverty and Inequality Report: Using the 6th Ghana Living Standards Survey 2016.

Ellis, F., \& Freeman, H. A. (2004). Rural Livelihoods and Poverty Reduction Strategies in Four African Countries. Journal of Development Studies, 40, 1-30. https://doi.org/10.1080/00220380410001673175

Galeano, E. (2009). Open Veins of Latin America: Five Centuries of the Pillage of a Continent. Serpent's Tail.

Hansard (2014, February 5). Plight of Head Potters (Kayayei) in Ghana. Parliamentary Debates Official Report, Parliament of Ghana.

Harris, J. R., \& Todaro, M. P. (1970). Migration, Unemployment and Development: A Two Sector Analysis. American Economic Review, 60, 126-142.

International Institute for Population Sciences (IIPS) \& ICF (International Coaching Federation). (2017). National Family Health Survey (NFHS-4), 2015-2016: India. International Institute for Population Sciences.

International Organisation for Migration (2018). IOM in Zimbabwe. https://zimbabwe.iom.int/sites/default/files/Docs/IOM\%20Zimbabwe\%20AR 25Aug20 16 Highres.pdf

Jehu-Appiah, C., Aryeetey, G., Spaan, E., de Hoop, T., Agyepong, I., \& Baltussen, R. (2011). Equity Aspects of the National Health Insurance Scheme in Ghana: Who Is Enrolling, Who Is Not and Why? Social Science \& Medicine, 72, 157-165.

https://doi.org/10.1016/j.socscimed.2010.10.025

Kitching, G. (2011). Class and Economic Change in Kenya: The Making of an African Petit Bourgeoisie 1905-1970. Yale University Press.

Kwankye, S. O. (2012). Independent North-South Child Migration as a Parental Investment in Northern Ghana. Population, Space and Place, 18, 535-550.

https://doi.org/10.1002/psp.682

Kwankye, S. O., Anarfi, J. K., Tagoe, C. A., \& Castaldo, A. (2007, January) Coping Strategies of Independent Child Migrants from Northern Ghana to Southern Cities. Migration DRC Working Paper No. T-23. Development Research Centre on Migration, Globalisation and Poverty, University of Sussex.

Kwankye, S. O., Anarfi, J. K., Tagoe, C. A., \& Castaldo, A. (2009, February). Independent North-South Child Migration in Ghana: The Decision Making Process. Working Paper No. T-29. Development Research Centre on Migration, Globalisation and Poverty, University of Sussex.

Leventi, C., Sutherland, H., \& Tasseva, I. (2017). Improving Poverty Reduction in Europe: What Works Best Where? EUROMOD Working Paper No. EM8/17. Colchester: ISER, University of Essex.

Liu, T., \& Chan, K. W. (2001). Internal Migration in China and Its Database: An Assessment. China Information, 15, 75-113. https://doi.org/10.1177/0920203X0101500203

McCormick, B., \& Wahba, J. (2005). Why Do the Young and Educated in LDCs Concentrate in Large Cities? Evidence from Migration Data. Economica, 72, 39-67. https://doi.org/10.1111/j.0013-0427.2005.00401.x

Mudege, N. N., \& Zulu, E. M. (2011). In Their Own Words: Assessment of Satisfaction with Residential Location among Migrants in Nairobi Slums. Journal of Urban Health, 
88, 219-234. https://doi.org/10.1007/s11524-010-9467-z

Nwajiuba, C. H. (2011). Migration and Livelihood in South East Nigeria. In Doppler, W., \& S. Bauer (Eds.), Farming and Rural Systems Economics (Vol. 67, pp. 22-37). Weikersheim.

Ojuolape, N. (2021). UNFPA Collaborate with Chief Justice Mentorship Program to Help Kayayei. Daily Graphic, 21722, 13. http://www.graphic.com.gh

Okorie, P. (2002). Prospects of Food Self Reliance. Perspectives of Food Security in Eastern Nigeria. In W. Doppler, \& S. Bauer (Eds.), Farming and Rural Systems Economics (Vol. 46, pp. 18-31). Weikersheim.

Olajide, O. A (2013). Male Migrant's Perceptions of Agricultural Problems and Benefits of Rural Urban Migration in Oyo State Nigeria. International Journal of Agricultural Science, 3, 11-28.

Onweagba, A., \& Chukwu, A. (2011). Consequences of Poverty for Youth Migration in Migration and Livelihood in South East Nigeria. In W. Doppler, \& S. Bauer (Eds.), Farming and Rural Systems Economics (Vol. 67, pp. 36-51). Weikersheim.

Oxford Dictionaries (2018). Livelihood. https://en.oxforddictionaries.com/definition/livelihood

Oyvat, C. (2016). Agrarian Structures, Urbanization and Inequality. World Development, 83, 207-230. https://doi.org/10.1016/j.worlddev.2016.01.019

Perroux, F. (1955). Note sur la Notion de Pole de Croissance. Harlow Économie appliqué, $8,307-320$.

Raza, M., \& Habeeb, A. (1976). Characteristics of Colonial Urbanization: A Case Study of Satellite Primacy of Calcutta (1850-1921). In A. Pokshiskevsky (Ed.), Urbanization in Developing Countries (pp. 187, 196-197, 218). Rupa Publications.

Roberts, K. D. (2002). Female Labour Migrants to Shanghai: Temporary "Floaters" or Settlers? International Migration Review, 36, 492-519.

https://doi.org/10.1111/j.1747-7379.2002.tb00090.x

Schultz, T. P. (1982). Lifetime Migration within Educational Strata in Venezuela: Estimates of a Logistic Model. Economic Development and Cultural Change, 30, 559-593. https://doi.org/10.1086/452576

United Nations Development Programme (UNDP) (1999). China Human Development Report 1999: Transition and the State. http://www.undp.org.cn/downloads/nhdr/nhdr1999.pdf

United Nations Population Fund (UNFPA) (2012). Marrying Too Young: End Child Marriage. https://www.unfpa.org/sites/default/files/pubpdf/MarryingTooYoung.pdf

United Nations (2017). International Migration Report.

http://www.un.org/en/development/desa/population/migration/publications/migration report/docs/Migr ationReport2017 Highlights.pdf

Van den-Berg, C. (2007). The Kayayei: Survival in the City of Accra. Master of Philisophy Thesis, University of Amsterdam.

Visaria, P. M (1969). Migration between India and Pakistan, 1951-61. Demography, 6, 323-334. https://doi.org/10.2307/2060400

Wang, F.-L. (2005). Organizing through Division and Exclusion: China's Hukou System. Stanford University Press. https://doi.org/10.1515/9780804767484

Wilson, A., \& Mittelmark, M. (2013). Resources for Adjusting Well to Work Migration: Women from Northern Ghana Working in Head Porterage in Greater Accra. Africa Today, 59, 25-38. https://doi.org/10.2979/africatoday.59.4.25 
Yeboah, M. A. (2010). Urban Poverty, Livelihood, and Gender: Perceptions and Experiences of Porters in Accra, Ghana. Africa Today, Bloomington, 56, 42-60. https://doi.org/10.2979/aft.2010.56.3.42

Yeboah, M. A., \& Appiah-Yeboah, K. (2009). An Examination of the Cultural and Socio Economic Profiles of Porters in Accra, Ghana. Nordic Journal of African Studies, 18, $1-21$.

Zhu, N. (2002). The Impacts of Income Gaps on Migration Decisions in China. China Economic Review, 13, 213-230. https://doi.org/10.1016/S1043-951X(02)00074-3

Zhu, Y. (2000). In Situ Urbanization in Rural China: Case Studies from Fujian Province. Development and Practice, 31, 413-434. https://doi.org/10.1111/1467-7660.00160 


\section{Appendix: Interview Guide}

The challenges of curbing North-South Migration of teenage girls in Ghana

Section A: Demographic Features of Respondent

1) Gender: $\square$ Male $\square$ Female

2) Age Range

\begin{tabular}{cccccc}
\hline Years & $9-12 \mathrm{yrs}$ & $13-15 \mathrm{yrs}$ & $16-18 \mathrm{yrs}$ & $17-19 \mathrm{yrs}$ & Above 19 \\
\hline Tick $(\sqrt{ })$ & & & & & \\
\hline
\end{tabular}

3) What is your highest academic qualification?

$\square$ No School $\square$ Lower Primary $\square$ Upper Primary

$\square$ JHS $\quad \square$ SHS $1 \quad \square$ SHS $2 \quad \square$ SHS 3

4) Vocation training status before migrating?

$\square$ No trade skills $\square$ Under-apprenticeship $\square$ Left Apprenticeship mid-stream

$\square$ Completed Apprenticeship

$\square$ No money to establish trade

$\square$ Helping with family's farming work

5) How many girls have you helped to migrate to the South?

6) Marital Status

$\square$ Have you been betrothed to a man for marriage?

$\square$ Are you married already?

$\square$ How many wives does your husband have and what position are you in your matrimonial home?

$\square$ Are you a young widow?

7) What are your plans for the future?

\section{Section B}

Objective One i.e. to identify factors that promote North-south migration of teenage girls in Ghana

1) Why did you leave the North to the South?

2) How did you get to Accra from the North?

3) Where do you sleep in Accra?

4) What problems do you face at where you sleep?

\section{Section C}

Objective Two i.e. to examine the employment opportunities available to migrated teenage girls in Ghana

1) What kind of work do you and friends do when you came to Accra or Kumasi from the North?

2) To what extent is the business you do help you in life? 
3) How friendly are your employers to you?

\section{Section D}

Objective Three i.e. to identify challenges facing stakeholders' effort at curbing the North-south migration of teenage girls in Ghana

1) Why do you think the sector ministry of women and children has not done anything about the teenage migration situation in the country?

2) Why have parents in the North not been able to discourage their children from migrating to the south for menial jobs?

\section{Section E}

Objective four i.e. to explore strategies for discouraging North-south migration of teenage girls in Ghana

1) What efforts do you think can be made in the North to stamp out migration of teenage girls to the South?

2) What arrangements can be made by the sector ministry of children and women affairs to address this problem of teenage girls' migration from the North in the long run?

3) What can be done in the interim to generally address the migration issue of teenage girls from the north to the south to do menial jobs?

Thank You 